
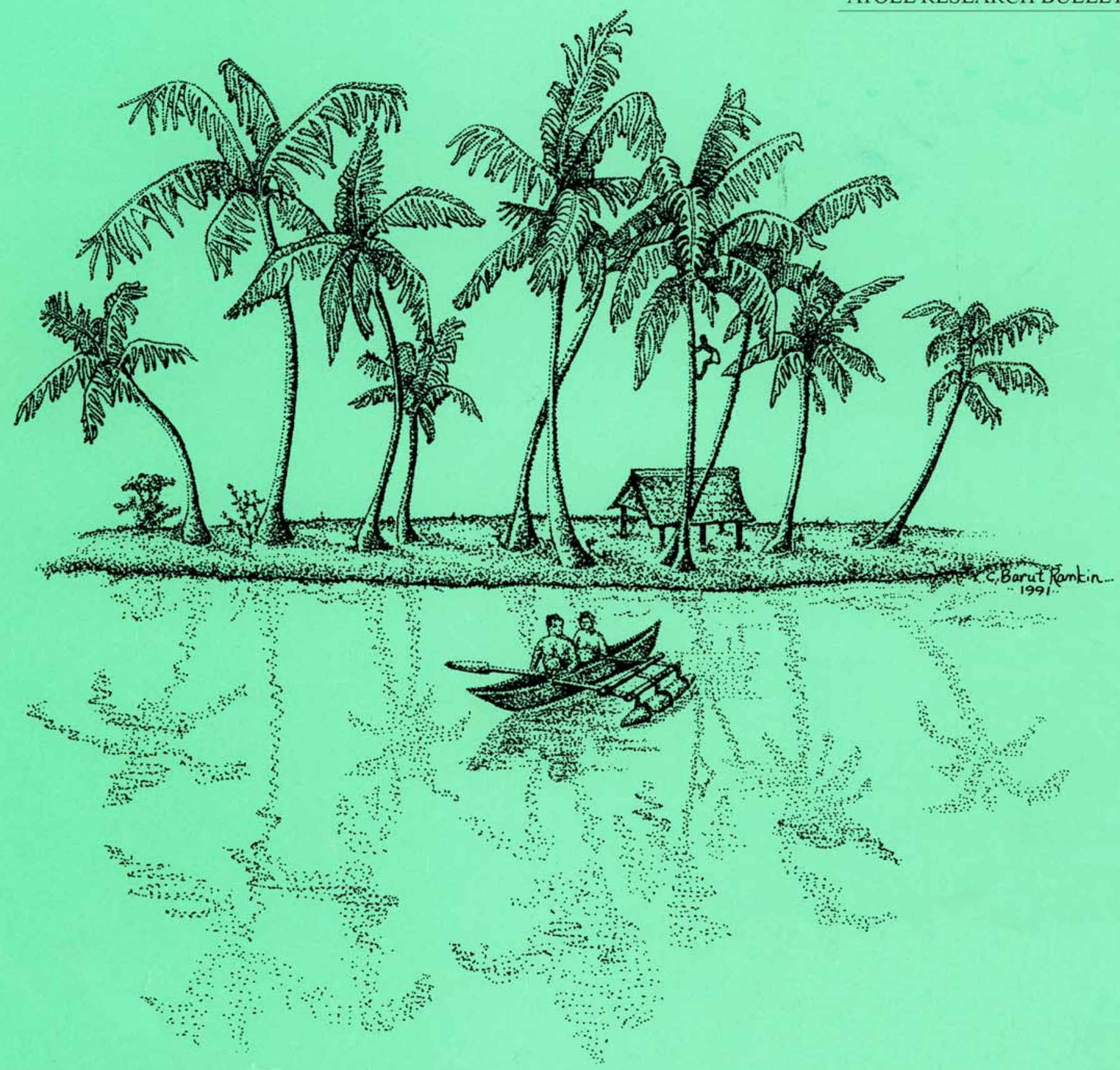

CORAL BLEACHING AND MORTALITY IN THE

CHAGOS ARCHIPELAGO

Charles Sheppard, Anne Sheppard, Andrew Mogg,

Dan Bayley, Alexandra C. Dempsey, Ronan Roche, John Turner, and Sam Purkis

Smithsonian Institution Scholarly Press

\section{ATOLL}

RESEARCH

BULLETIN 


\section{CORAL BLEACHING AND MORTALITY IN THE CHAGOS ARCHIPELAGO}

Charles Sheppard, Anne Sheppard, Andrew Mogg, Dan Bayley, Alexandra C. Dempsey, Ronan Roche, John Turner, and Sam Purkis

Atoll Research Bulletin No. 613 • 2 November 2017 Scholarly Press

Washington, D.C. 
All statements made in papers published in the Atoll Research Bulletin are the sole responsibility of the authors and do not necessarily represent the views of the Smithsonian Institution or of the editors of the bulletin. Articles submitted for publication in the Atoll Research Bulletin should be original papers and must be made available by authors for open access publication. Manuscripts should be consistent with the "Author Formatting Guidelines for Publication in the Atoll Research Bulletin." All submissions to the bulletin are peer reviewed and, after revision, are evaluated prior to acceptance and publication through the publisher's open access portal, Open $\mathrm{SI}$ (http://opensi.si.edu).

\section{Published by SMITHSONIAN INSTITUTION SCHOLARLY PRESS}

P.O. Box 37012, MRC 957

Washington, D.C. 20013-7012

https://scholarlypress.si.edu/

The rights to all text and images in this publication are owned either by the contributing authors or by third parties. Fair use of materials is permitted for personal, educational, or noncommercial purposes. Users must cite author and source of content, must not alter or modify the content, and must comply with all other terms or restrictions that may be applicable. Users are responsible for securing permission from a rights holder for any other use.

ISSN: 0077-5630 (online) 


\title{
CORAL BLEACHING AND MORTALITY IN THE CHAGOS ARCHIPELAGO
}

\author{
CHARLES SHEPPARD ${ }^{1 *}$, ANNE SHEPPARD ${ }^{1}$, ANDREW MOGG $^{2}$, DAN BAYLEY $^{3}$, ALEXANDRA $^{2}$ \\ C. DEMPSEY ${ }^{4}$, RONAN ROCHE$^{5}$, JOHN TURNER $^{5}$, and SAM PURKIS ${ }^{6}$
}

\begin{abstract}
The atolls and coral banks of the Chagos Archipelago (British Indian Ocean Territory) in the central Indian Ocean were severely affected by the El Niño Southern Oscillation (ENSO) thermal event that started in 2015 and which lasted for nearly two years. On these reefs, coral mortality reduced scleractinian coral cover from $40 \%-50 \%$ to $<10 \%$ and commonly to only about $5 \%$ in water less than $15 \mathrm{~m}$ depth. The three-dimensional structure of the reefs was significantly reduced as a result, and the prolonged warming almost eliminated soft corals. Most atolls of the archipelago are uninhabited, so any changes are driven by broad environmental changes rather than by direct, local anthropogenic effects. Coral cover was first measured in 1978, temperature loggers have recorded water temperature at various depths for the last 11 years, and the results of the recent warming event are placed in this context. Over this time, cover has declined severely along with a general rise in water temperature of one-third of a degree Celsius on ocean reefs and by more than one-half of a degree Celsius in lagoons. Major fluctuations of coral cover caused by warm episodes have sometimes, but not always, coincided with ENSO events and have occurred on top of the increasing trend in background temperatures. Juvenile coral populations have also recently severely declined following the mortality of the adults. Estimates of calcification suggest a marked reduction, from a state of vigorous reef growth that had not long recovered from the earlier severe warming event of 1998, to a state of net erosion. Predictions suggest that recurrences of mass mortalities will take place too frequently for any significant recovery of reef health in these atolls by the late $2020 \mathrm{~s}$.
\end{abstract}

Keywords: Chagos Archipelago, coral reefs, ocean warming, atolls, coral bleaching, sea temperature

\section{INTRODUCTION}

The Chagos Archipelago consists of five atolls with islands and numerous submerged banks in the British Indian Ocean Territory, central Indian Ocean (Figure 1). Only the southernmost atoll Diego Garcia is inhabited, supporting a military facility on its western side. The other atolls became uninhabited variously in the 1930s or 1970s, following an era of coconut plantations that lasted nearly two centuries.

\footnotetext{
${ }^{1}$ School of Life Sciences, University of Warwick, Coventry CV4 7AL, UK

${ }^{2}$ Natural Environment Research Council National Facility for Scientific Diving, Scottish Association for Marine Sciences, Scottish Marine Institute, Oban, Argyll PA37 1QA, Scotland, UK

${ }^{3}$ Natural History Museum of London, Cromwell Rd, South Kensington, London SW7 5BD, and

Centre for Biodiversity and Environment Research, University College London, Gower Street, London WC1E 6BT and

Zoological Society of London, Regent's Park, London, England NW1 4RY5

${ }^{4}$ Khaled bin Sultan Living Oceans Foundation, 130 Severn Ave \#100, Annapolis, MD 21403, USA

${ }^{5}$ School of Ocean Sciences, Bangor University LL59 5AB, UK

${ }^{6}$ Center for Carbonate Research, Dept. of Marine Geosciences, RSMAS, University of Miami, 4600 Rickenbacker Causeway, Miami, FL 33149, USA

* Corresponding author: charles.sheppard@warwick.ac.uk
} 


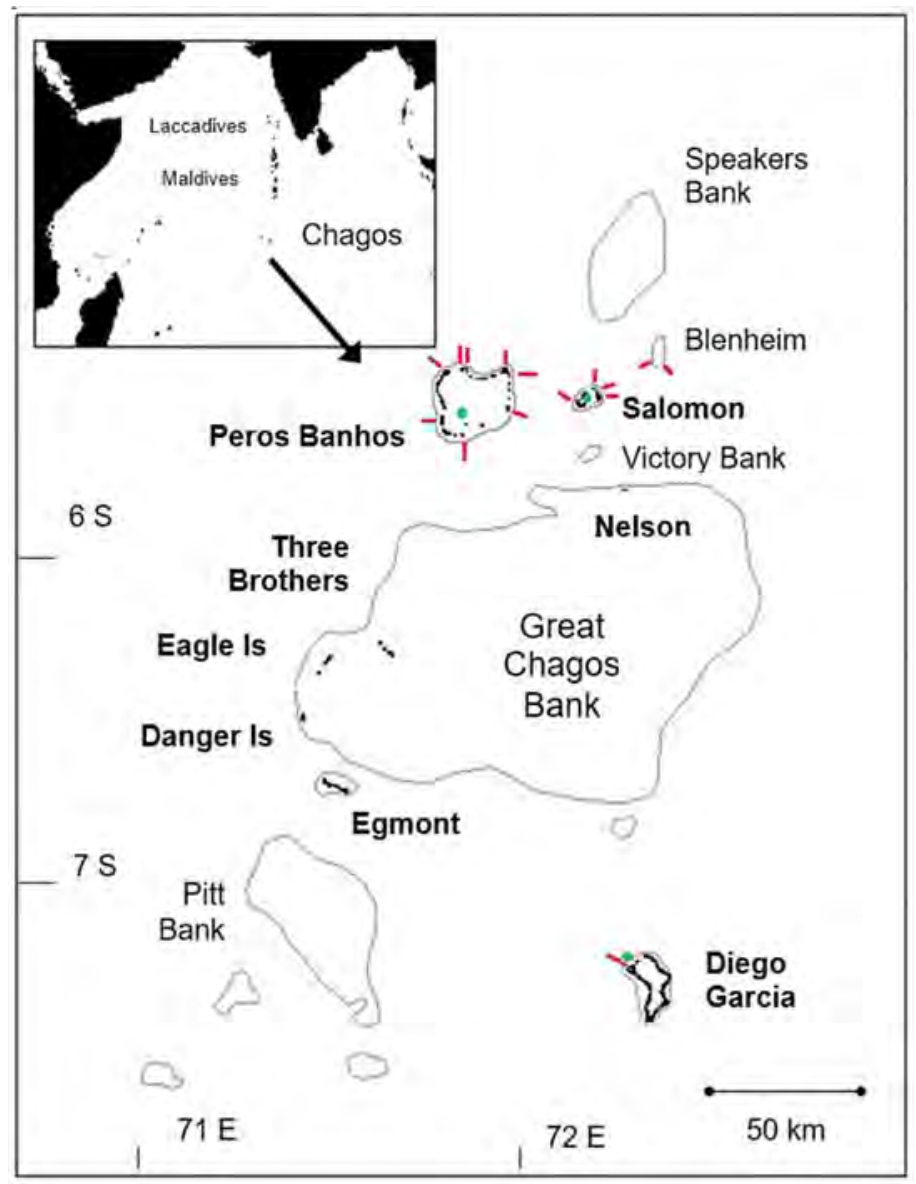

Figure 1. Map of Chagos atolls and sampling locations. All atolls have been examined on numerous but irregular occassions. Data from all atolls are used in discussion of cover since 1996. In 2017 the survey was confined to the northern atolls only where red lines point to the oceanfacing reef sites focussed upon here. Surveys of coral cover, juveniles and the photo transects of ocean-facing reefs were undertaken in 2017.

Green dots mark sites where the data loggers were recovered in 2017. (Numerous other sampling sites and loggers exist and continue around central and southern atolls but are not marked here for clarity.) For Diego Garcia, the temperature loggers (green dot) were recovered in November 2016, and the red line shows were juveniles were also counted in 2012.

The archipelago is located at a critical geographical position for species movements, being at a 'crossroads' between the east and west halves of the Indian Ocean, and it serves as a stepping stone, refuge and reservoir in the larval transport pathways of many species (Sheppard et al., 2013: 227). Its key location caused Veron et al. (2015:9) to call it the "Chagos Stricture" with regard to Indian Ocean marine species distributions. Before the present El Niño Southern Oscillation (ENSO) thermal event (hereafter called 'warming event') that started in 2015 , the $60,000 \mathrm{~km}^{2}$ of shallow substrate of the Chagos Archipelago contained about half of all reefs in the Indian Ocean that remained in good condition (Sheppard et al., 2012, fig. 8).

Recognition of its biological importance caused the entire area to the 200 nautical mile boundary to be declared a Marine Protected Area in 2010. However, because it has been mainly uninhabited (apart from the southern atoll Diego Garcia) since the early 1970s and has been a virtual exclusion zone since then, it has been a de facto protected area for about 50 years. As such, the Chagos Archipelago fulfils all the criteria shown by Edgar et al. (2014) for a valuable MPA, as well as those recently enumerated by Roberts et al. (2017) for aiding mitigation of climate change. The present condition of reefs of Chagos in today's era of accelerating climate change (IPCC, 2014) is therefore of great importance.

One reason for the archipelago's scientific importance is that, because of its lack of a permanent population, it experiences minimal direct or local impacts from fishing, sewage, industrial effluents or shoreline alterations. Thus, any ecological changes it experiences are likely to be mainly or only those caused by major or global environmental perturbations, including the increasing trend in water temperature which is tied to global climate change factors and to ENSO oscillations. Importantly also, 
these reefs demonstrate that there is a distinction, usually overlooked, between the different sets of factors that might initially kill corals from those which might then inhibit recovery once warming has abated (Ateweberhan et al., 2011, 2013). Many areas around the world including Chagos showed similarly severe coral bleaching and mortality after the severe warming event of 1998, but many of those which had ongoing, direct and local impacts recovered only slowly or not at all, while the reefs of Chagos, and others that had minimal local impacts, recovered their primary reef builders after about seven years and had regained a full canopy of large framework Acropora after 7-10 years (Ateweberhan et al., 2013; Sheppard et al., 2012). The reefs therefore provide information not only on effects of ocean warming on coral reefs in the absence of any confounding local factors such as pollution and over-extraction of resources, but also of what factors are important to subsequent recovery.

An island-based research expedition visited the atolls in 1978-1979, followed by ship-based research visits to the area at irregular intervals since 1996. Data on coral cover have been obtained intermittently over this time, showing progressive changes (Sheppard et al., 2012, 2013). In addition to these surveys, numerous temperature data recorders have been deployed at various depths to $25 \mathrm{~m}$ since 2006, which have helped to track the progress of temperature trends over the past decade. Here we focus on the responses to the long 2015-2016 warming event but also bring together previous incremental surveys to show broad changes in coral cover resulting from bleaching, from the first structured recordings in this area until the present day. This long-term view is intended to provide context to the consequences of the recent warming, which has been particularly severe and prolonged (NOAA 2016a). There have been few other accounts to date documenting the magnitude and ecological effects of this ENSO warming event on coral reefs, and these mostly discuss its physical parameters (e.g., Heron et al., 2016), a notable exception being that of Hughes et al. (2017) regarding a large survey on the Great Barrier Reef which lost a large proportion of its corals.

\section{METHODS}

\section{Coral Survey Methods}

Figure 1 shows the locations across the atolls where various types of sampling were undertaken. Our principal survey methods in 2017 were similar to those used in all years since 1996 (Sheppard et al., 2012, 2013), where the intention has been to build up an increasing time series of observations. The same observers performed the measurements and counts in all years. In brief, coral cover was measured by eye within quadrats of side $0.5 \mathrm{~m}$, coupled with eye and video observations of much larger extents at each site. The sites include lagoons and ocean-facing slopes. To be consistent with earlier reports we focus mainly on ocean-facing sites, but include lagoons where illustrative, and we state when data are restricted to some atolls only. Measurements of coral cover were taken at intervals of $5 \mathrm{~m}$ from $5 \mathrm{~m}$ to $25 \mathrm{~m}$ depths, as in all preceding years. Each time several hundred quadrats were measured, with a total of over 600 quadrats measured in the survey of 2017. Data from 1978 is also incorporated for coral cover analysis; this used a line transect method which was not replicated.

For the 2015 survey, ten-minute video sequences were recorded across $5 \mathrm{~m}$ depth intervals from $5 \mathrm{~m}$ to $25 \mathrm{~m}$. Scale was provided by two $638 \mathrm{~nm}$ (red) wavelength lasers mounted below the camera to project dots $10 \mathrm{~cm}$ apart. In addition, approximately 80 wide-angle habitat images were recorded randomly on each dive by a camera with a red filter, recording at 30 -second intervals. Fifty random frame grabs from each depth and site were imported into Coral Point Count (CPCe, Kohler and Gill, 2006) and overlaid by 16 randomly generated points. The substrate and benthic life form under each were collated into Excel in $\mathrm{CPCe}$ for analysis.

In 2017, large-scale digital model reconstructions of the reef surface were created using 'Structure from Motion' photogrammetry (Westoby et al., 2012) at six shallow (5-10m) sites across the Northern atolls. Wide angle HD images were collected at approximately 2 meters above the sea floor using cameras set to a capture rate of $2 \mathrm{~Hz}$. Filming followed a lawn-mower pattern to facilitate maximum overlap 
between images following Burns et al. (2015). These resulted in an approximately $400 \mathrm{~m}^{2}$ planar area 3D reconstruction, with known values of scale, orientation and depth, enabled through use of an in situ spirit level and compass. Scaling error through extrapolation was minimised through the placement of markers throughout the reef area of interest.

Juvenile corals were counted, defined here as those less than $15 \mathrm{~m}$ in longest dimension. This size range was chosen as being most likely to include only newly settled colonies less than about one year old. Most of those recorded were in fact considerably smaller, with only the fast growing Acropora being at or near the $15 \mathrm{~mm}$ limit. Large $10 \mathrm{~cm}$-diameter magnifying lenses aided methodical examination of all 600

quadrats. Juveniles had been counted in earlier years also, in approximately 300 quadrats of $25 \mathrm{~cm}$ side on ocean-facing reefs in Diego Garcia in 2012 and in a slightly lower number of quadrats at several atolls in 2013. All results are expressed as numbers per $\mathrm{m}^{2}$ of hard substrate that was not occupied already by coelenterates or sponges. To assess the accuracy of our estimates of juveniles, fluorescent photogrammetry was conducted at Peros Banhos Atoll in 2017, where fluorescing juveniles were counted in areas of substrate roughly $600-700 \mathrm{~cm}^{2}$ in size, in high detail. Images were photographed using a 450 $\mathrm{nm}$ wavelength pass filter and illuminated using a Sea and Sea YS-02 (Nightsea) strobe with a $450 \mathrm{~nm}$ wavelength excitation filter.

\section{Temperature Measurements in Chagos at Different Depths 2006-2017}

A series of temperature loggers (Tempcon, Inc.) have been deployed across the archipelago at $5 \mathrm{~m}, 15$ $\mathrm{m}$ and $25 \mathrm{~m}$ depths, on various ocean facing slopes and lagoon slopes. These recorded ambient temperature at two hour intervals, and have been collected and replaced as opportunity allowed, usually at intervals of 1,2 or 3 years. These were initially placed at all three depths on each transect across several atolls. Overall, the recovery success was about $75 \%$, though it was found that those placed at $5 \mathrm{~m}$ on ocean slopes were more commonly lost, effectively ending those shallow series. Others were lost due to various factors such as reef erosion and fish bites on plastic cable ties. A few series continued throughout the time span from 2006 to the present, while others have missing intervals during this time. Three representative series are included.

\section{Sea Level and ENSO}

Relative sea level data from the tide gauge at Diego Garcia were accessed in September 2017 (http://uhslc.soest.hawaii.edu/data/: Diego Garcia is site number 104) and are plotted. Data are 'research grade', using a combination of pressure sensor, radar and float sensor with encoder (IOC 2017), though the two most recent years shown are unverified 'fast delivery' data at present. The trend is matched with the Multivariate ENSO index (MEI) for the same period (Wolter and Timlin, 1998; http://sealevel.colorado.edu/, accessed September 2017) and its relationship with water temperature is also explored.

\section{RESULTS}

\section{Coral Cover}

In 2017, corals were seen to have experienced very heavy mortality from the 2015-2016 warming event, especially in water shallower than about $15 \mathrm{~m}$ depth. Figures 2 and 3 from exactly the same site in Salomon Atoll illustrate this mortality. Figure 4 summarizes scleractinian coral cover over the full time series from 1979 to present, with each line showing cover at $5 \mathrm{~m}$ depth intervals to $25 \mathrm{~m}$. This uses data on ocean facing reefs only for consistency of comparison between years. The consequences of the recent 


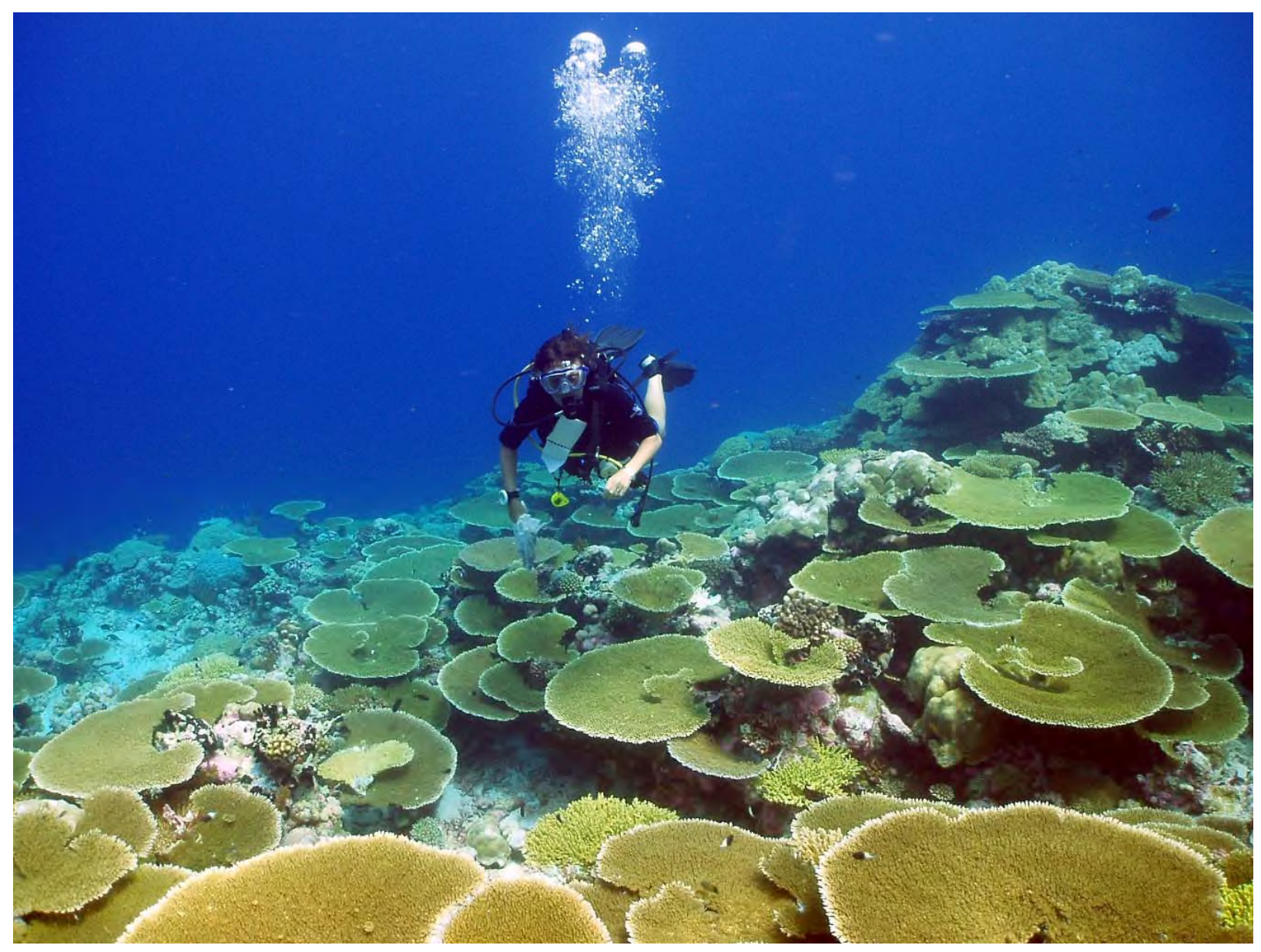

Figure 2. Western facing ocean reef on Salomon Atoll in 2006, dominated by the table coral Acropora cytherea. Location is southern tip of Isle Anglais, 12-15 $\mathrm{m}$ depth.

warming are clear. The Multivariate ENSO index is also displayed. The lines in the earlier half of the series of coral cover measurements are displayed as dashed because no sampling was done between 1979 and 1996, and it is likely that the decline in cover during that period was not smooth but was episodic or stepped as is seen from 1998 to present. The pink bars in Figure 4 show the alignment of the known, most severe warming events with coral cover. The reductions in cover during the two most recent events in 1998 and 2015 are clear, and possibly the two strong ENSO events earlier during the period when no measurements took place had broadly similar effects. During the most recent two decades, the recovery after 1998 lasted for about the next 14 years, until the warming that started in 2015. A dip in coral cover in 2014 has been attributed to a reduction mainly in tabular Acropora corals, caused by diseases and senescence; further details of this recovery during the period 1998 to 2015 are given in Sheppard et al. (2012, 2013).

In April 2015, live scleractinian coral cover remained over 40\%. Some corals appeared pale in colour but there was no detectable mortality. One month later in May 2015, however, a resurvey showed (Figure 5 ) that about $30 \%$ of corals were bleached to varying extents at all depths measured (Figures 6,7). The affected colonies mostly appeared to be alive with a cover of transparent tissue. The survey carried out the 


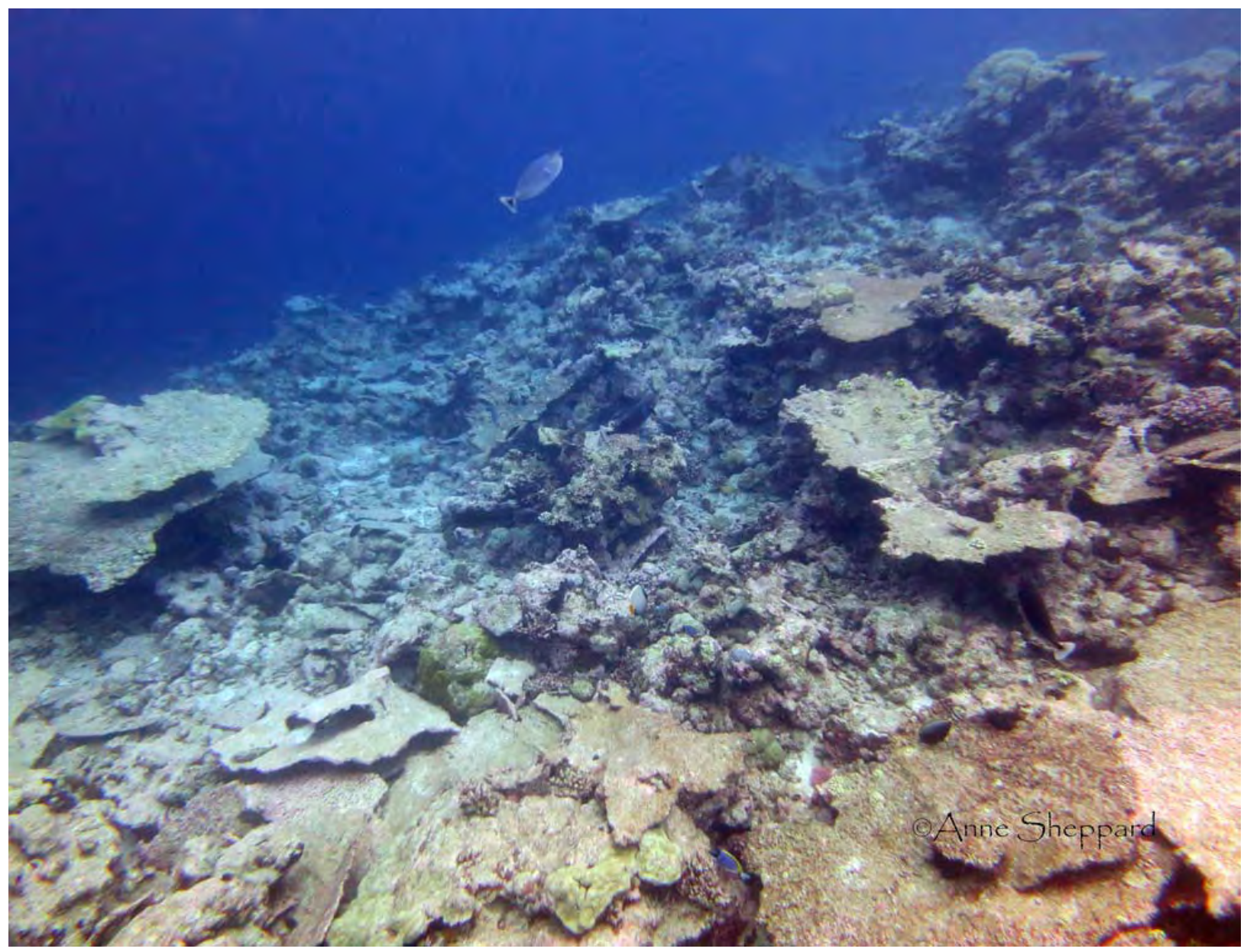

Figure 3. The same ocean reef on Salomon Atoll as in Figure 2, taken in 2017.

following year in 2016 showed that high mortality had occurred. In 2017, the coral cover data show that further mortality had taken place, leaving a very low coral cover of usually $5 \%-15 \%$. The error bars are small, showing the near-universal condition in these northern atolls, and some sites contained almost no living colonies at all in shallower depths. In addition, there were almost no surviving soft corals on the reefs shallower than about $15 \mathrm{~m}$ depth.

The extent of damage to coral cover seen over a large scale affected the reef topography as well. Ortho-rectified image mosaics are shown for two representative locations in the northern atolls of Peros Banhos and Salomons (Figures 8, 9). These show an almost complete die-off of living corals at the 5-10 $\mathrm{m}$ depth band, with one site showing only $2.3 \%$ live coral cover across a $200 \mathrm{~m}^{2}$ planar reef area. Results show a severe reduction of the $3 \mathrm{D}$ structure of the reef that is so important to maintaining habitat and species diversity. ${ }^{7}$

Following the 1998 mortality, several opportunistic species, notably the tabular Acropora cytherea, rapidly dominated most reefs over a fairly broad depth span between 5-20 m depth (Sheppard et al., 2013). Whereas cover took just a little more than a decade to recover after 1998, diversity remained conspicuously reduced for much of this time. In the years following 2012, the tabular corals, many at

\footnotetext{
${ }^{7}$ Scalable orthomosaics of six additional sites can be obtained from A.M. on request (Andrew.Mogg@sams.ac.uk), as can cmscale photogrammetric models using the method of Burns et al. (2015) covering a total of $8,926 \mathrm{~m}^{2}$ over 16 sites for greater analysis of complexity, coral coverage and carbonate production.
} 
maximum diameter over $1.5 \mathrm{~m}$, suffered mortality from diseases, notably white band disease, natural senescence and bioerosion. These declined significantly (Wright, 2016), allowing a more diverse assemblage of larger colonies to develop. All species were seen to be affected in 2017.

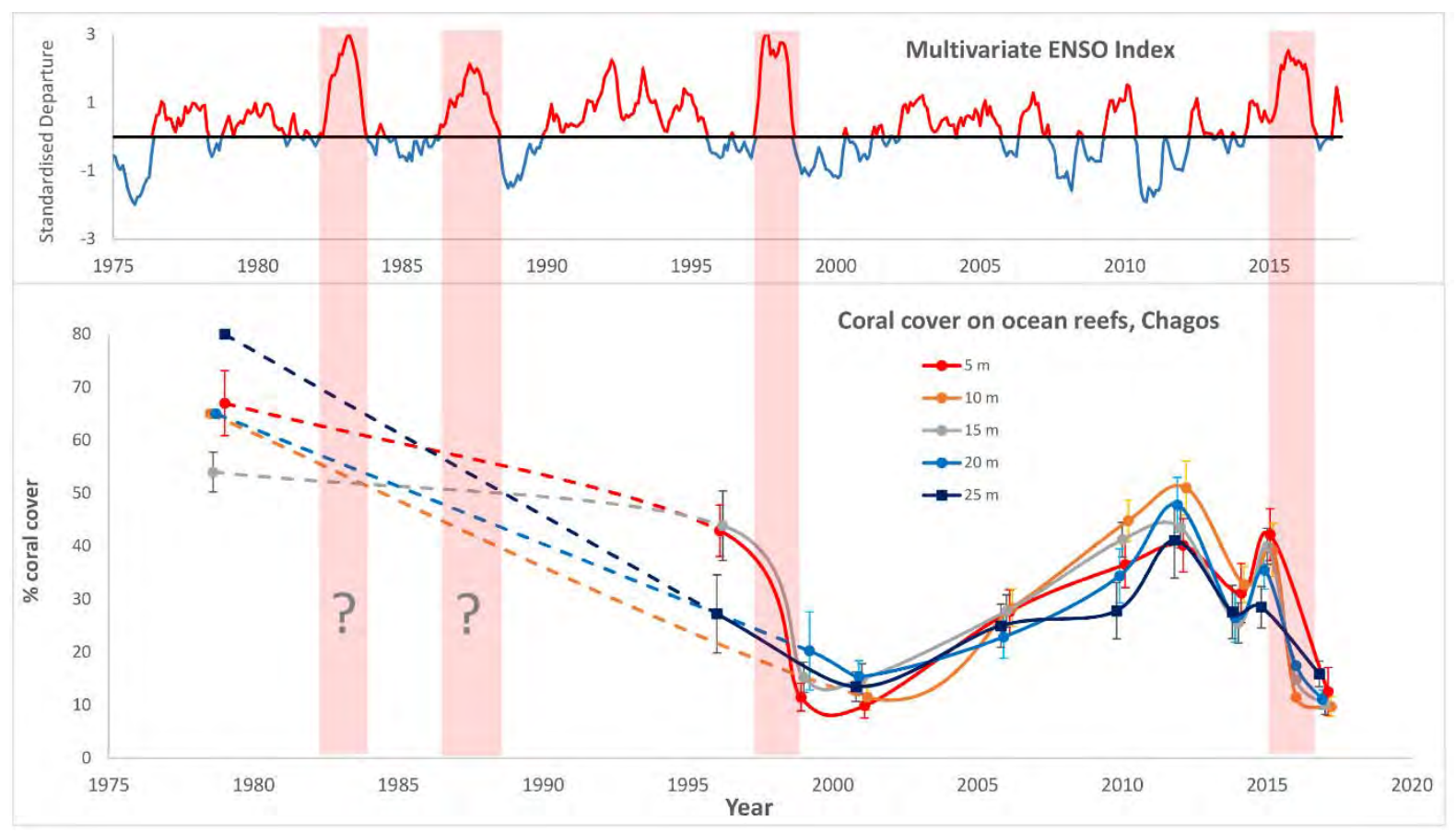

Figure 4. Coral cover values of all combined sites in the archipelago on ocean-facing slopes, with time. Each line is a different depth. Error bars are std. errors. For the Multivariate ENSO Index, data is taken from https://www.esrl.noaa.gov/psd/enso/mei/table.html. Between 1978 and 1996, where no measurements took place, the lines are broken because it is unlikely that their slopes are smooth in reality. The pink vertical bars mark the most notable warming events. The two rightmost bars show a good alignment with widespread coral declines. The two leftmost pink bars marked with '?' show where the cover might likewise have declined in a stepped manner. 


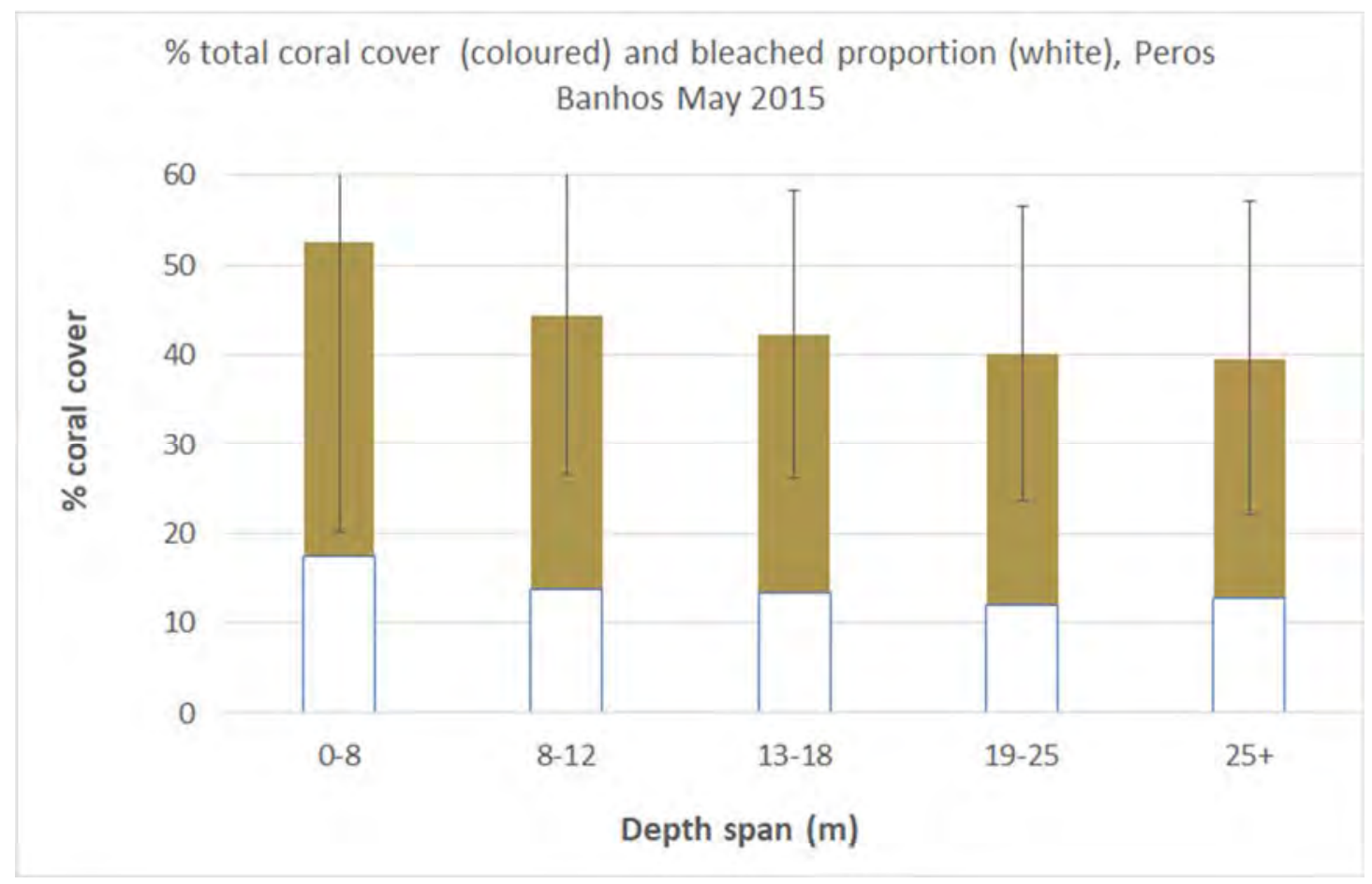

Figure 5. Coral cover in various depth spans on Peros Banhos Atoll in May 2015, with the proportion that are bleached shown in the lower, white part of each column.

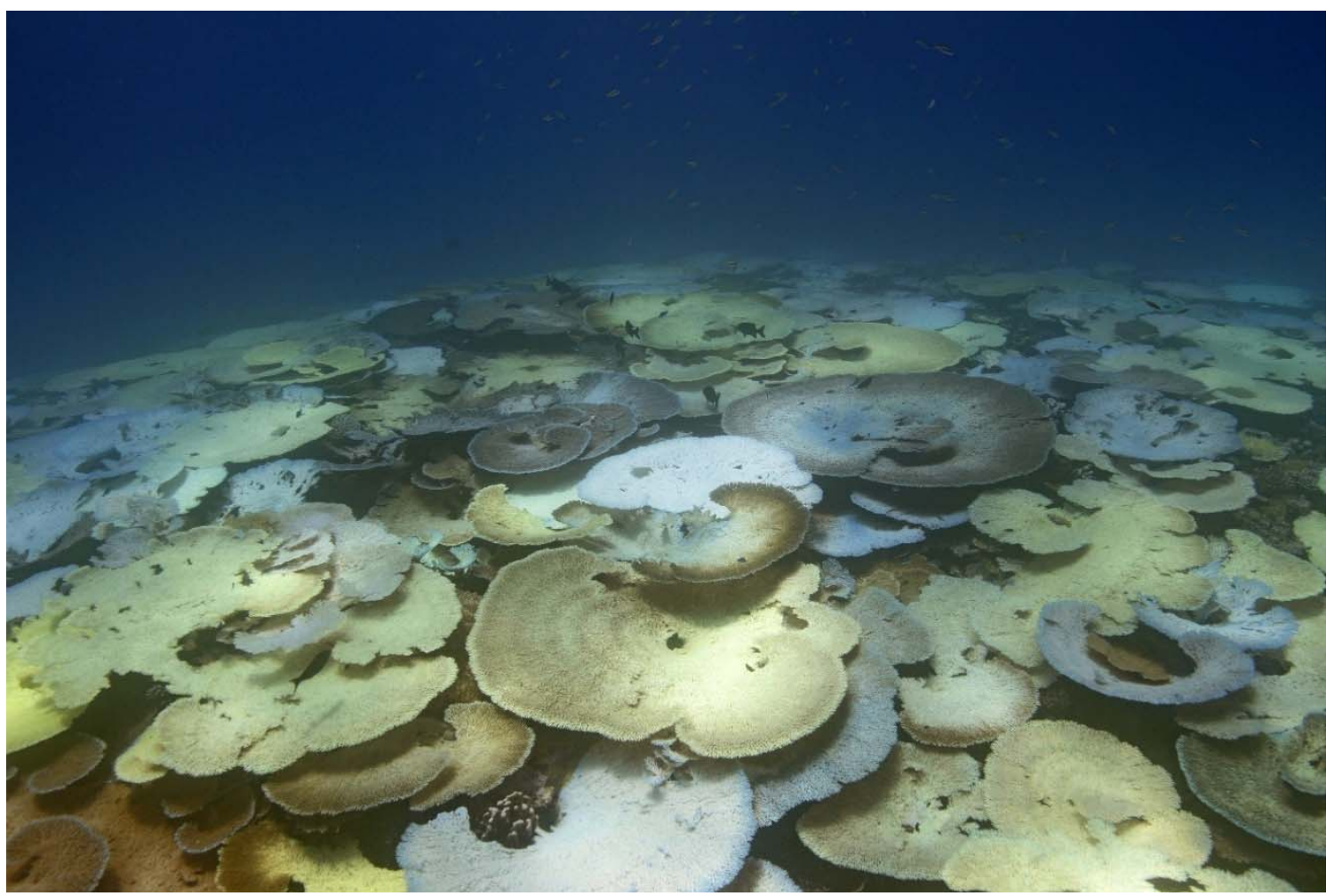

Figure 6. Scene in Peros Banhos Atoll at $15 \mathrm{~m}$ depth, in May 2015 showing several bleached table corals. Photo Derek Manzello/Khaled bin Sultan Living Oceans Foundation. 


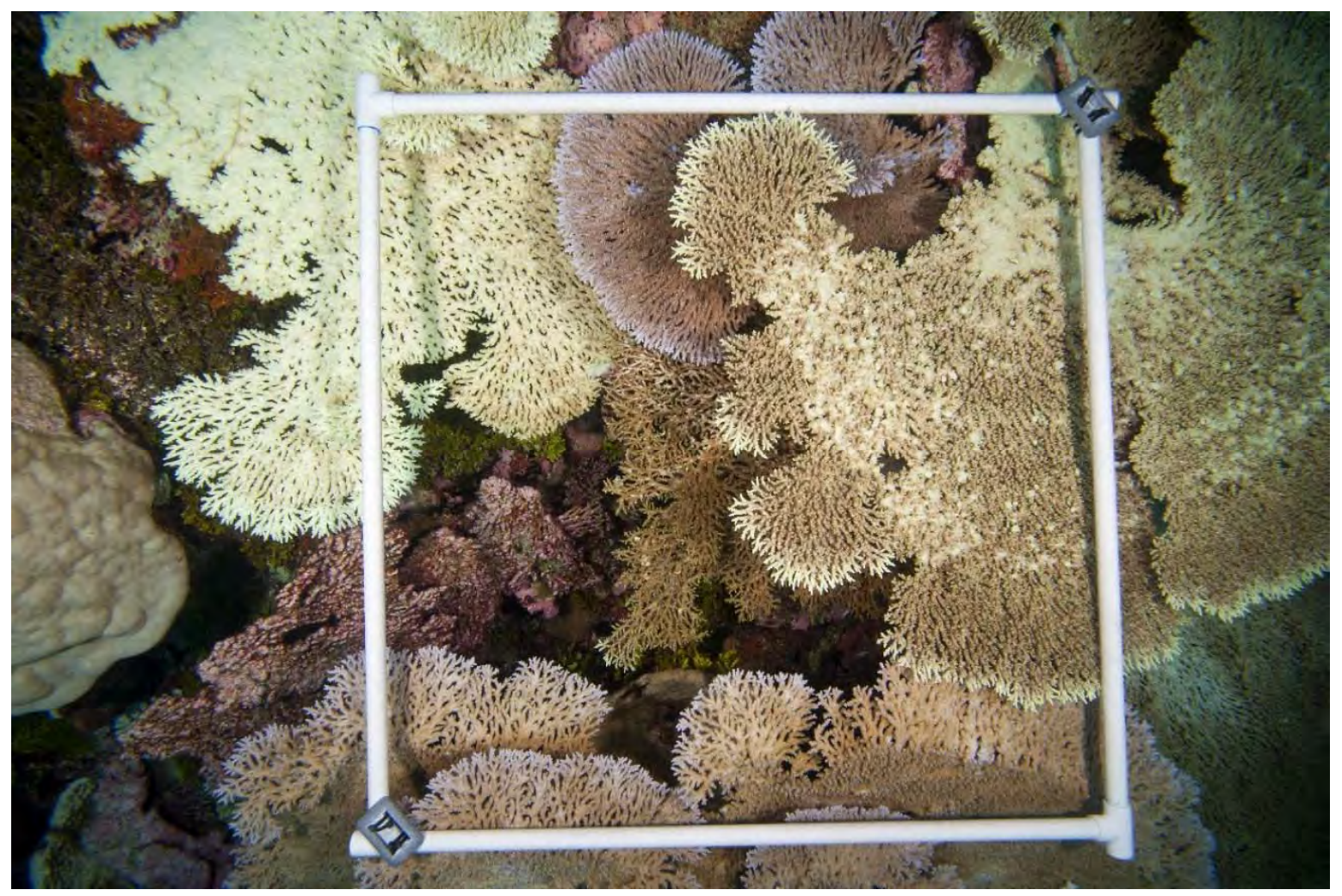

Figure 7. Quadrat for measuring proportion of bleached corals, $15 \mathrm{~m}$ depth, Peros Banhos Atoll, in May 2015. Photo Ken Marks/Khaled bin Sultan Living Oceans Foundation. 


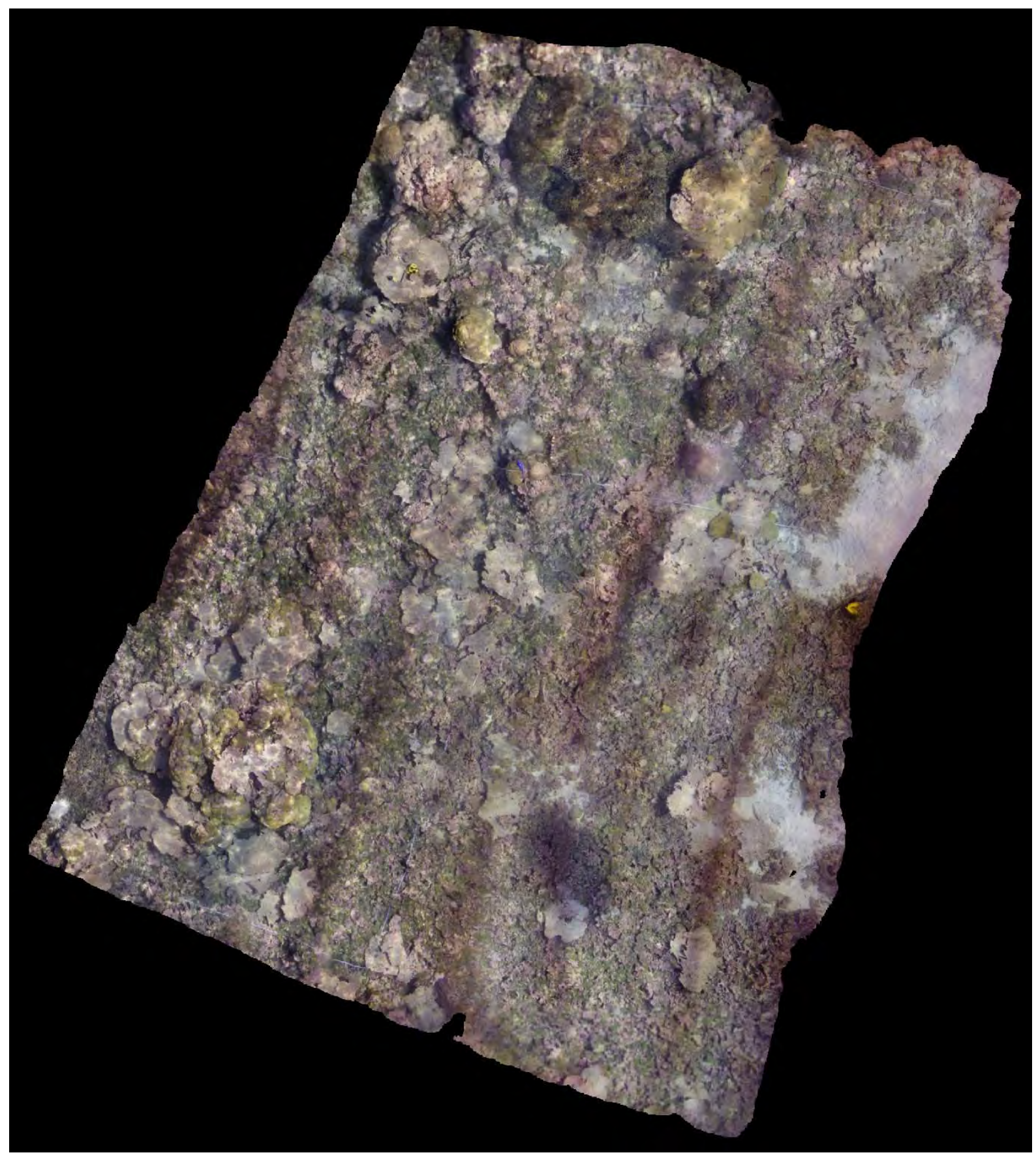

Figure 8. Typical broadscale benthic coral coverage in 2017 at $5 \mathrm{~m}$ within Ile Diamant lagoon, Peros Banhos Atoll. Imagery derived from SfM photogrammetry, with the image equivalent to a surface area of $\sim 250$ $\mathrm{m}^{2}$. Sparse Porites colonies are evident, along with a pronounced covering of Halimeda algae (dark green). 


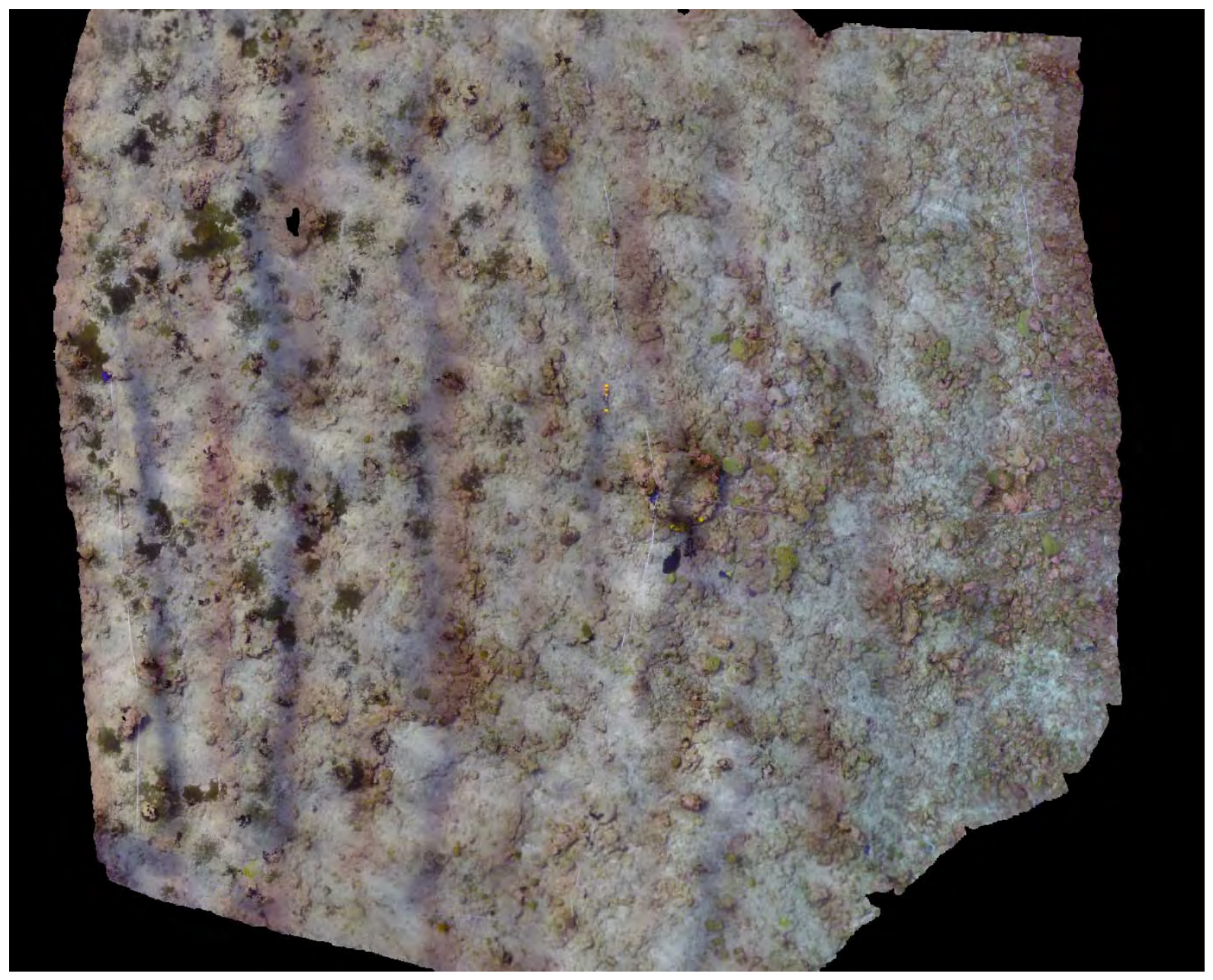

Figure 9. Typical broadscale benthic coral coverage in 2017 at $10 \mathrm{~m}$ on Ile Takamaka's exposed ocean-facing slope, Salomon atoll. Imagery derived from SfM photogrammetry, with the image equivalent to a surface area of $\sim 650 \mathrm{~m}^{2}$. Sparse Porites colonies are evident, along with sheets of the eroding sponge Cliona (dark patches).

\section{Water Temperature Trends}

Logger sites record a small increase in water temperature over time; the three longest time series are shown in Figure $10 \mathrm{a}-\mathrm{c}$. On one western ocean-facing reef in Diego Garcia the simple line of best fit showed a rise of $0.28^{\circ} \mathrm{C}$ over the 11-year span of instrument deployments, while in the relatively large, open and well mixed lagoon of Peros Banhos (Figure 10b), where depths reach $60 \mathrm{~m}$, the increase at $15 \mathrm{~m}$ depth was $0.36^{\circ} \mathrm{C}$ over this same period. In the much smaller, shallower lagoon of Salomon Atoll (Figure 10c), which has much more restricted water flow, the rise was greater, at $0.52^{\circ} \mathrm{C}$, over the shorter time period from 2009. These rises are similar to, or are greater than, many examples now being cited around the world (NOAA, 2016b).

On ocean-facing reefs in Chagos atolls including Diego Garcia (Figure 10a), a simple interpretation of average rise is greatly complicated by the fact that a deep, cold-water thermocline periodically moves vertically into the depth zones measured here (Sheppard, 2009). This happens markedly during the warmest part of the year; temperatures plunge by $6-8^{\circ} \mathrm{C}$ in a cyclical manner, with each cold cycle lasting 
3 to 4 days. This pattern was observed over all 11 years of measurements, with some years showing this more than others with no apparent periodicity. Lagoons do not show these temperature plunges.

Water temperatures are further examined by their exceedances over time above a fixed value, in a way analogous to degree heating weeks (Liu et al., 2003; Strong et al., 2004). The peak temperature that resulted in the mass mortality in 1998 as recorded from satellite information was $29.5^{\circ} \mathrm{C}$. This value is selected here initially as a threshold for determining the numbers of days each year which exceed bleaching levels (Figure 11), because the duration of any raised temperature is as important as the temperature itself for causing bleaching and mortality. In all cases, higher temperatures are far more common after 2015 than during the preceding decade. For the ocean facing reef slope in Diego Garcia, the number increased from about $1 \%-7 \%$ of days for most of the recorded span from 2006 , to nearly $18 \%$ of days in both 2015 and 2016. In the two lagoons, these increases were more marked; the percentage of days in 2015 and 2016 that exceeded $29.5^{\circ} \mathrm{C}$ in the more enclosed Salomon lagoon was more than 50\%.

Consequences of warmer water became evident in Salomon lagoon even before 2015, however. The lagoon is shallower than $30 \mathrm{~m}$, is relatively enclosed, and its bed was covered in corals, mostly leafy forms such as Echinopora lamellosa, Porites rus and Pachyseris (e.g., Schlager and Purkis, 2013). In March 2013, the corals on the lagoon floor were found to be almost completely dead (Figure 12, photo), and only those shallower than about $5 \mathrm{~m}$ depth, including Acropora and Porites, were still largely unaffected. Coral skeletons were still in growth position, so mortality had occurred relatively recently, presumably during the previous warm season of 2012-2013. An analysis by calendar year had shown that 2012 was significantly warmer than the preceding few years in terms of annual mean temperature (Figure 12, histogram) and, as can be seen from Figure 11, the period 2012-2013 was the first time that the proportion of days over $29.5^{\circ} \mathrm{C}$ exceeded $20 \%$ in Salomon lagoon.

The above measure differs from the Degree Heating Weeks (DHM; https://coralreefwatch.noaa.gov/satellite/index.php) metric for several reasons. In DHW the reference temperature is the climatological mean of nighttime satellite-derived sea surface temperatures of a prior 30 -year period, approximating to a threshold bleaching temperature. In this study the reference is the temperature known to have killed corals in 1998. DHW thresholds are surface temperatures, while our temperature loggers were located at $5 \mathrm{~m}$ and/or $15 \mathrm{~m}$ depth. Given the upwelling-driven temperature plunges already noted, our in situ measurements spanning full-day observations are considered more relevant to corals on ocean-facing reefs.

Figure 10. (next page) Water temperatures from three different atolls where relatively long series were obtained. (a) west facing ocean side, Diego Garcia $15 \mathrm{~m}$ depth with rate of temperature rise of $0.28^{\circ} \mathrm{C}$ over 11 years; (b) Lagoon knoll in Peros Banhos, $15 \mathrm{~m}$ depth, with rate of temperature rise of $0.36^{\circ} \mathrm{C}$ over 11 years; (c) lagoon knoll Salomon Atoll, $5 \mathrm{~m}$ depth with a rate of temperature rise of $0.52^{\circ} \mathrm{C}$, over $\sim 8$ years. Red lines are simple lines of best fit. 

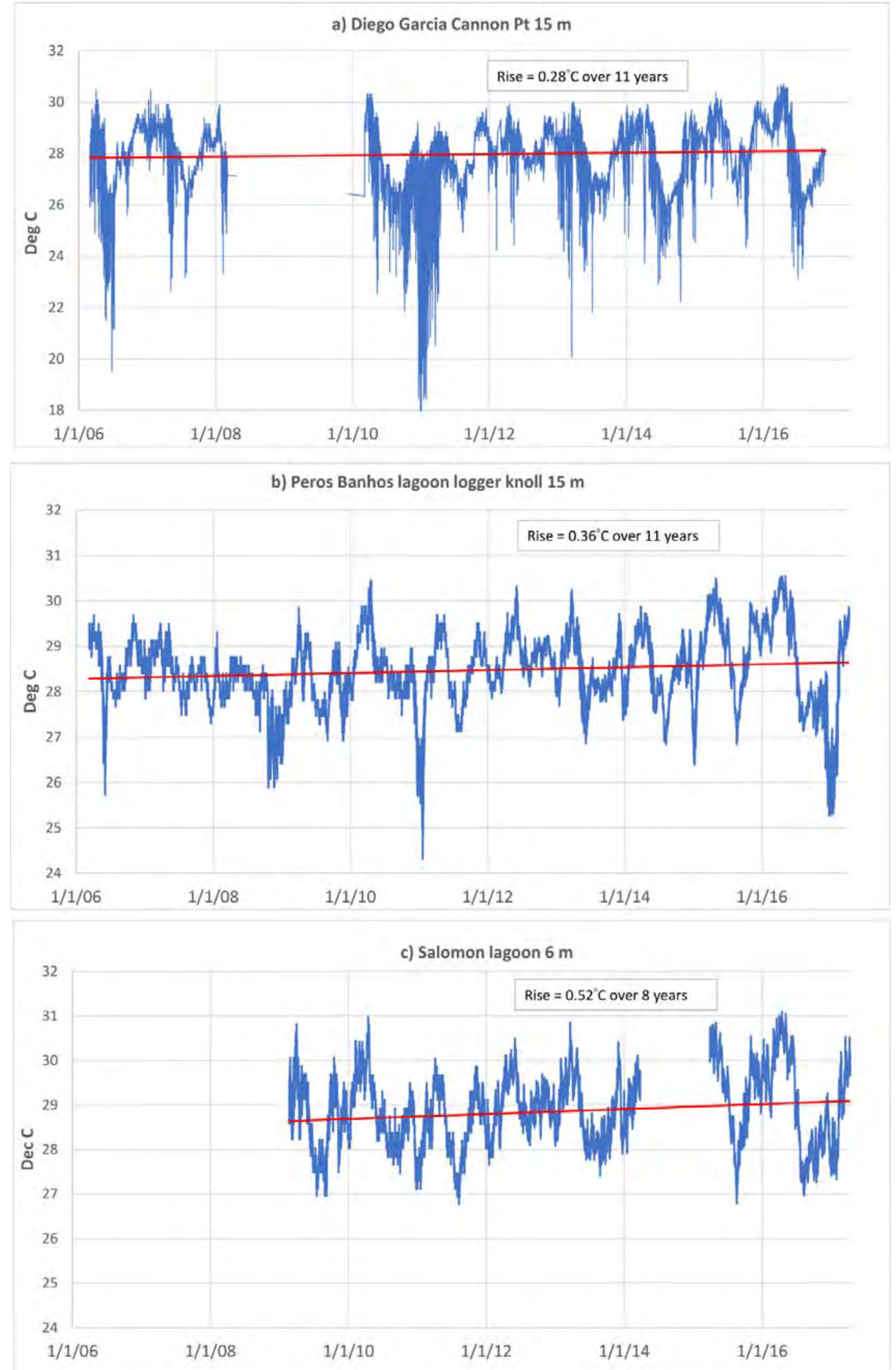

Figure 10 (caption on previous page) 


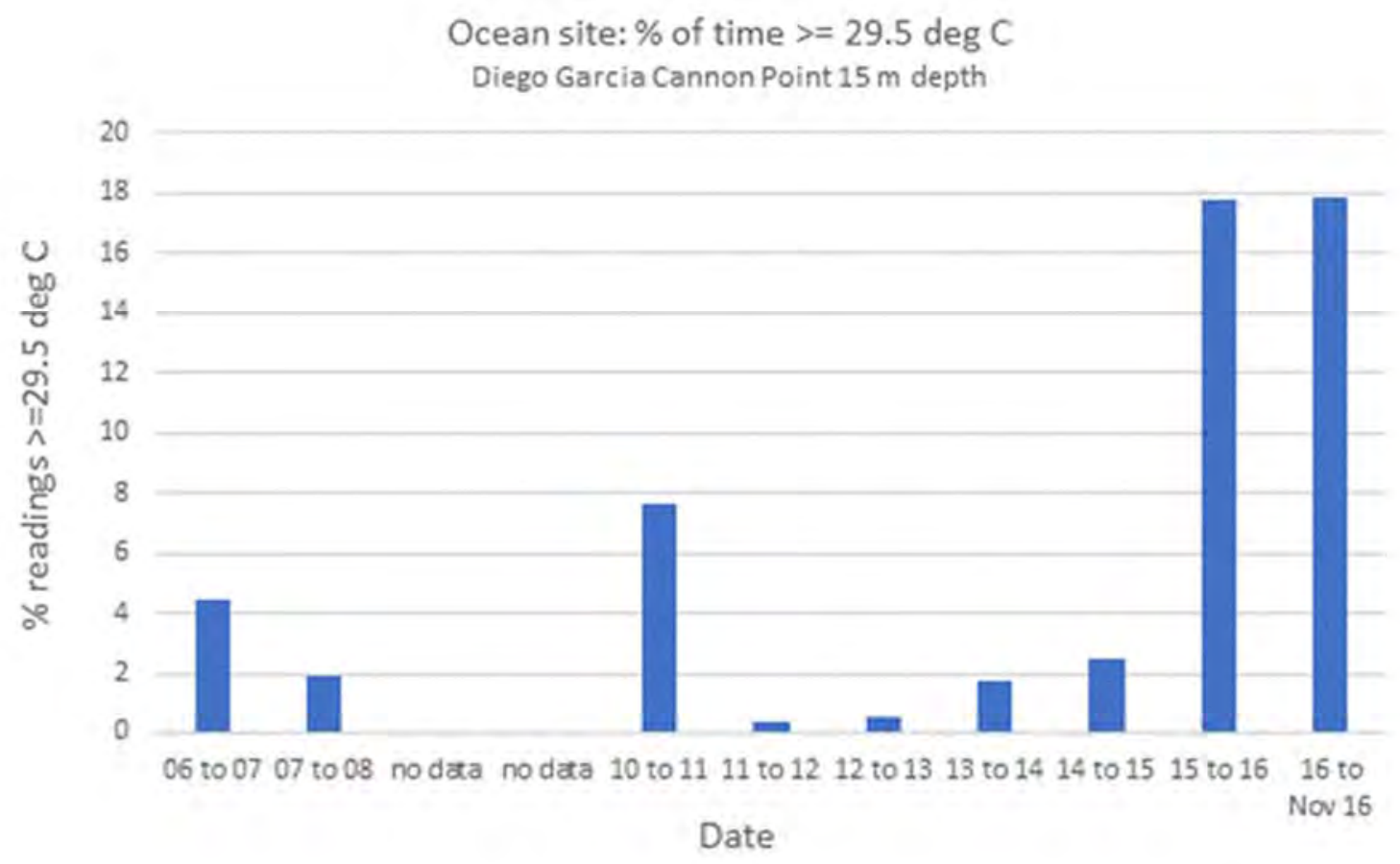

Lagoon sites: $\%$ of time $>=29.5 \mathrm{deg} C$

Peros Banhos $15 \mathrm{~m}$ depth, Salomon $5 \mathrm{~m}$ depth
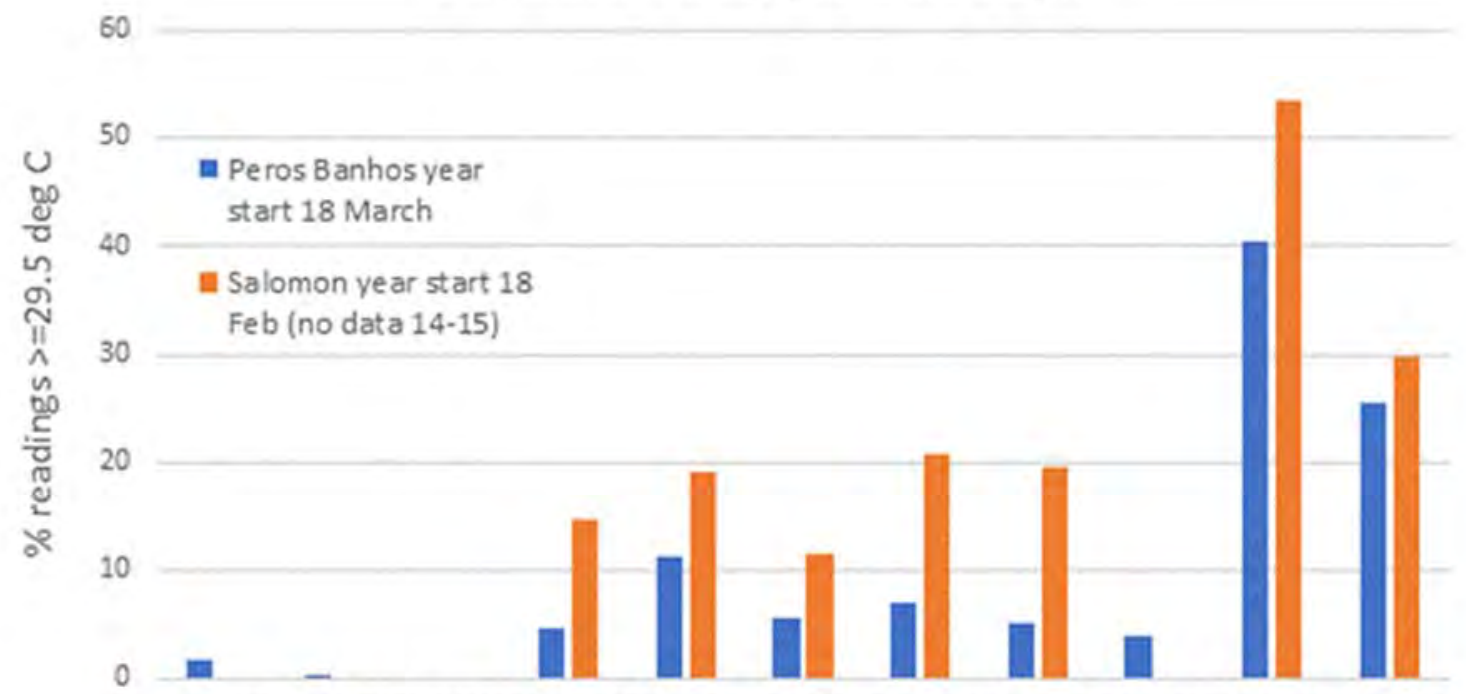

06 to 0707 to 0808 to 0909 to 1010 to 1111 to 1212 to 1313 to 1414 to 1515 to 1616 to 17

Date

Figure 11. The percentage of days that exceeded the bleaching threshold of $29.5^{\circ} \mathrm{C}$. (a) Ocean-facing site at Diego Garcia, (b) the lagoon sites in Peros Banhos (blue) and Salomon Atoll (orange). 

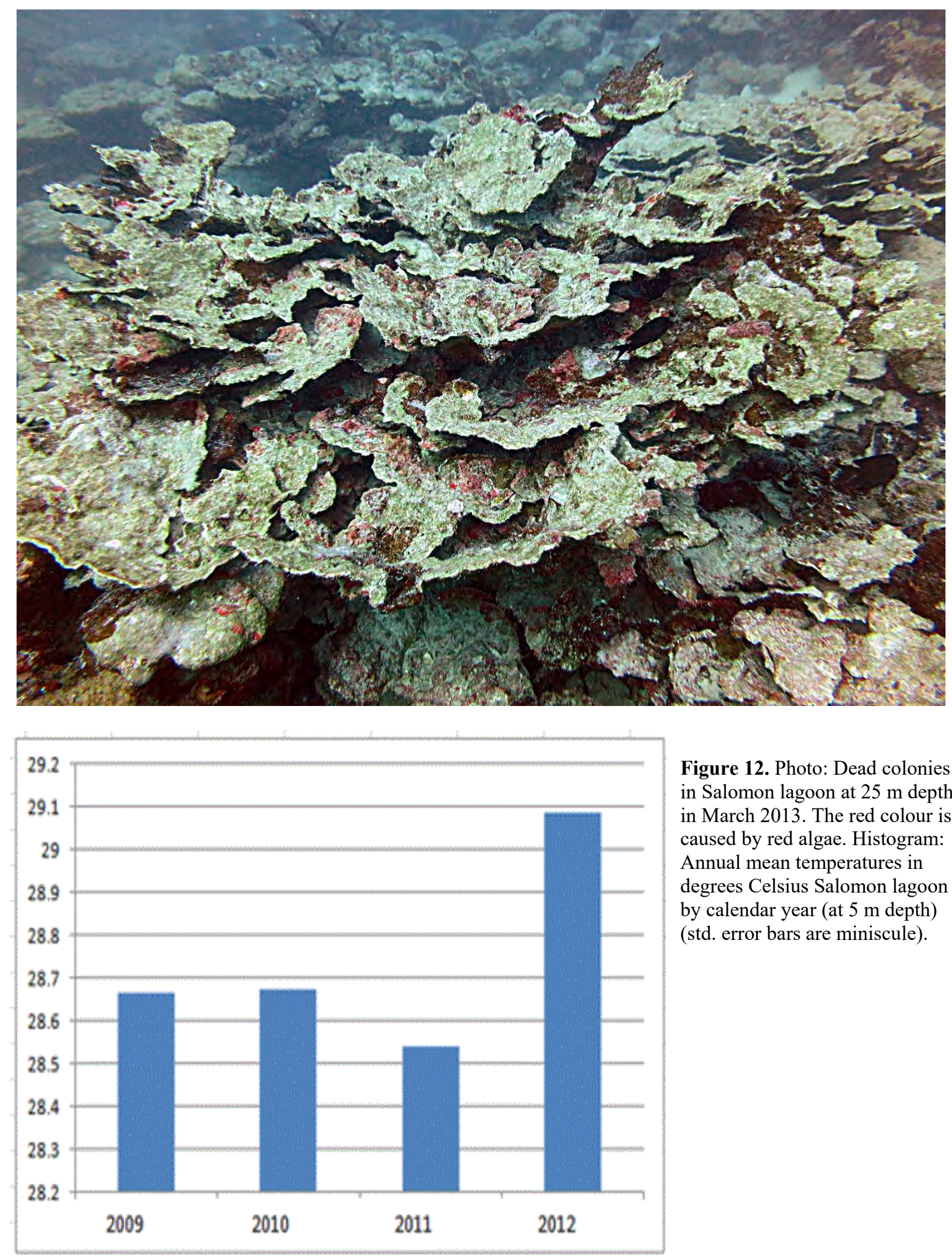

Figure 12. Photo: Dead colonies in Salomon lagoon at $25 \mathrm{~m}$ depth in March 2013. The red colour is caused by red algae. Histogram: Annual mean temperatures in degrees Celsius Salomon lagoon by calendar year (at $5 \mathrm{~m}$ depth) (std. error bars are miniscule). 


\section{Juvenile Corals}

Densities of juveniles in 2012 and 2013 ranged between 20-60 $\mathrm{m}^{-2}$ at all depths surveyed (Figure 13a-b). In 2017, numbers were significantly reduced to usually less than $10 \mathrm{~m}^{-2}$ on available hard substrate at all depths surveyed, and were completely absent from many locations. At all depths and all times, peak densities were found between $10 \mathrm{~m}$ and $15 \mathrm{~m}$ depth.

As in previous years, densities of juveniles were higher by one or two orders of magnitude on many dead table corals than they were on the firmer, more secure substrate between them. While some recruits on the table corals might develop, most will not survive the continuing disintegration of the tables - a pattern also seen after the 1998 event (Sheppard et al., 2002). The lower number of juveniles in 2017 is unsurprising given both the scarcity of adults in these shallower depths and the stress that surviving adults underwent.

Even though the surfaces of each quadrat were searched with a magnifying glass, the risk that juveniles were being overlooked amongst the light covering of fine filamentous algae on the coral-free substrate was assessed with fluorescent photogrammetry. This illuminates live coral tissue so that it stands out from the surrounding substrate. This also showed comparably low numbers. Figure 14 shows an example, consisting of a developing, single polyp less than $2 \mathrm{~mm}$ diameter. The method confirmed that the low numbers were not a result of difficulties in observing juveniles due to filamentous growth.

There seemed to be no selection of genera amongst the juveniles, with all major genera represented. The most common coral genera seen were Psammocora and the species Pavona varians, all relatively inconspicuous, small corals even when adult, though their dense skeletons may be important in reef framework construction. Amongst the larger group of juvenile or small corals that were at least one year old or more, Acropora was commonest, as observed in previous years. 

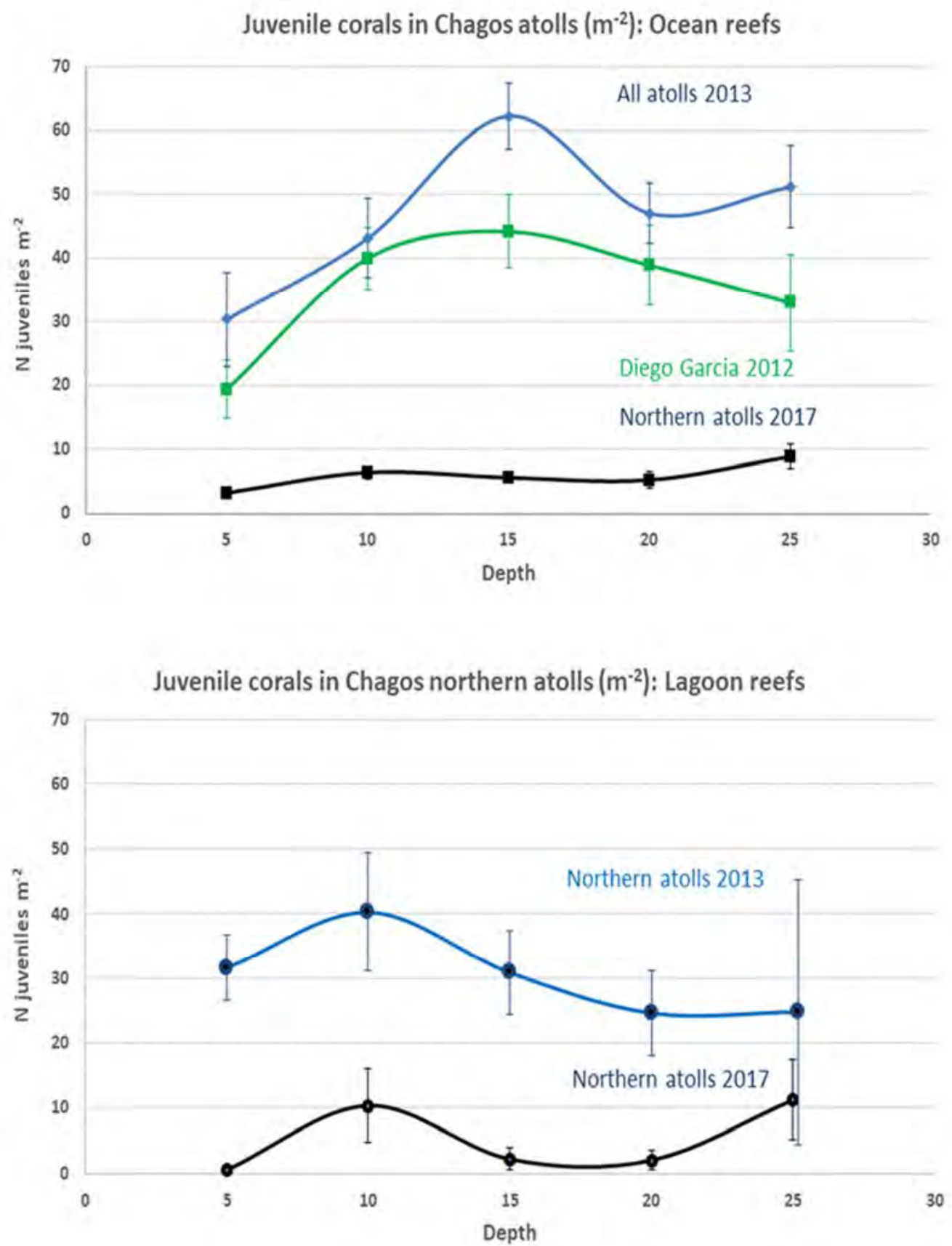

Figure 13. Numbers of juvenile coral colonies ( $>15 \mathrm{~mm}$ across) in (top) ocean facing reefs and (bottom) lagoon reefs, in different years. 


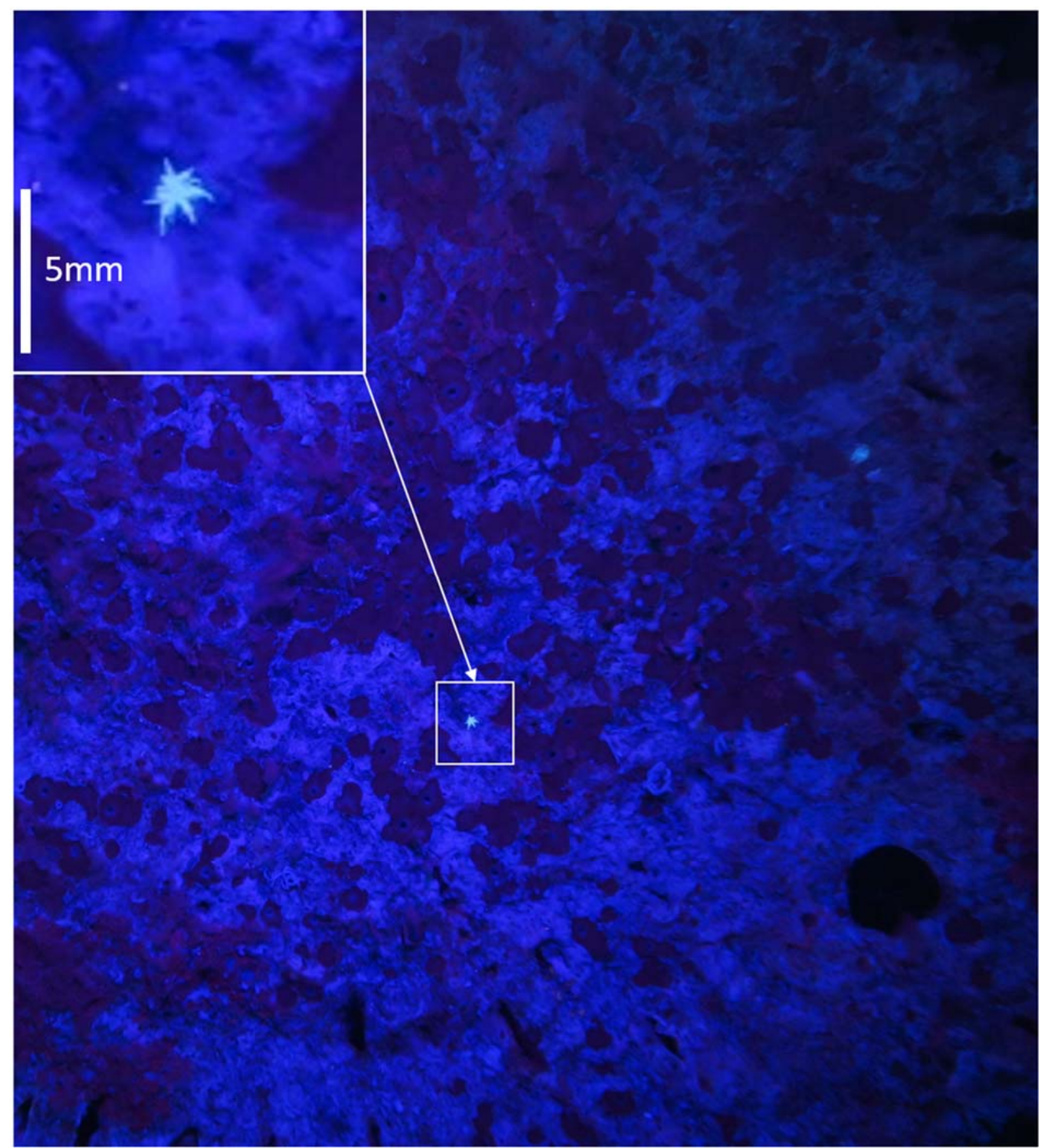

Figure 14. Blue light fluorescence image of one section of reef at $10 \mathrm{~m}$ depth, showing scarcity of polyp tissue overall, and one juvenile single polyp. Taken at site of Peros Banhos lagoon data logger of Figure 10b. 


\section{Sea Level Rise and Climatic Effects}

'Research Quality' sea level data of a single series is available from 2003 to 2015, with so-far uncorroborated data for the most recent two years, and Figure 15 (top) shows the rate of relative sea level rise for Diego Garcia is $6.22 \mathrm{~mm} \mathrm{y}^{-1}$. To aid interpretation of this, Figure 15 (middle) also plots the Multivariate ENSO index for this corresponding span, and Figure 15 (bottom) shows the water temperature rise (in this case monthly) for the most open lagoon, from 2006. This temperature series was chosen because this open lagoon has minimal water constriction but avoids the complicating plunges of temperature caused by the vertically moving thermocline that occurs on ocean-facing reefs (Sheppard, 2009).

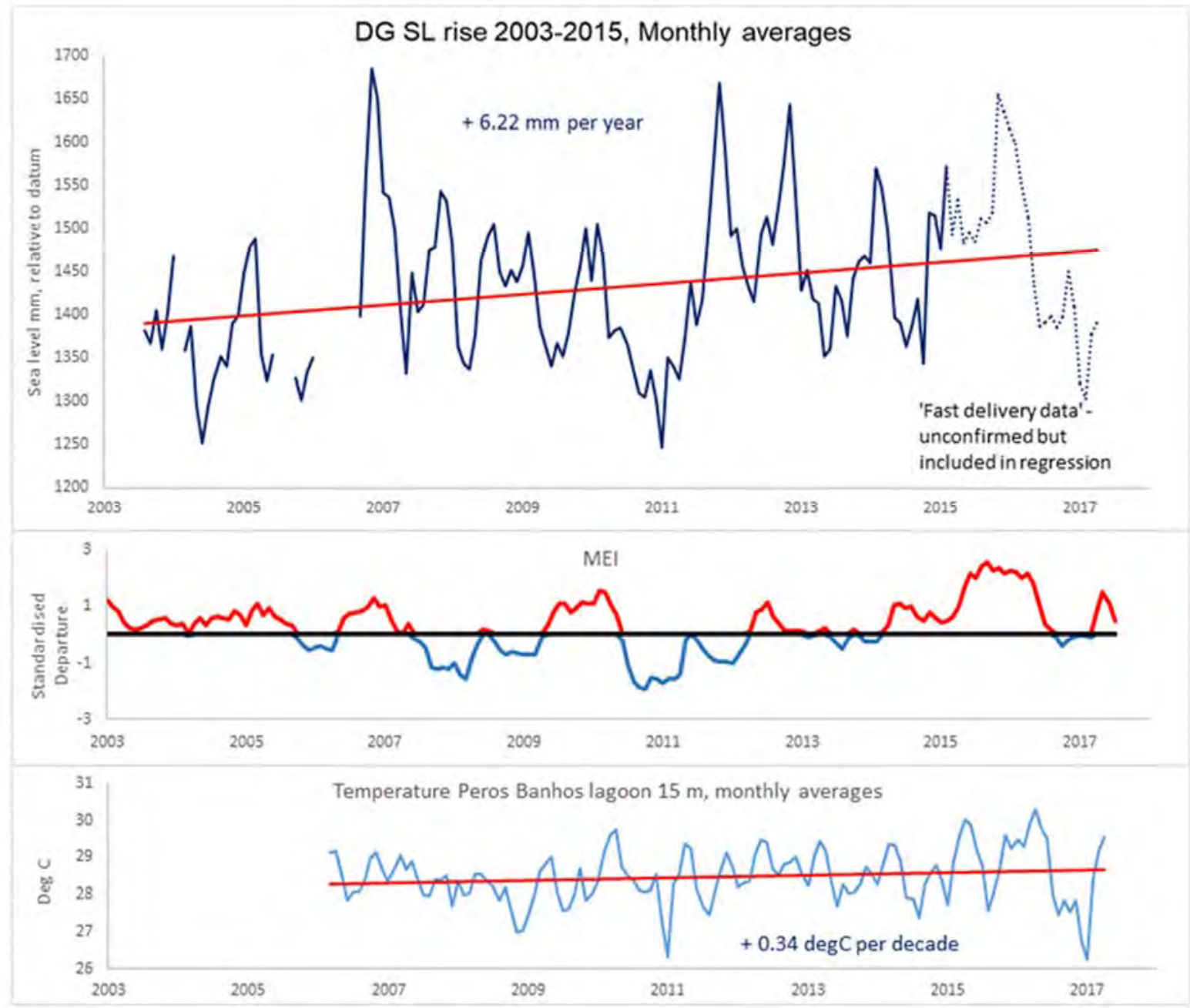

Figure 15. (top) Sea level data (monthly means) taken from the tide gauge at Diego Garcia. Based on these measurements, the rate of relative sea-level rise (i.e., that rate experienced by the atoll) is $6.37 \mathrm{~mm} \mathrm{yr}^{-1}$ for the period 2004 through 2015 (red line). Note that these data track relative and not eustatic sea level. (middle) Multivariate ENSO index (MEI) (Wolter and Timlin, 1998). Negative MEI values represent cold ENSO phase (La Niña), positive values warm ENSO phase (El Niño). (bottom) Water temperature in Peros Banhos lagoon, $15 \mathrm{~m}$ deep. 
The rate of local-relative sea level rise over this time is highly significant $(p=.001)$. Relative sea level changes include any subsidence of Diego Garcia. The rate of $6.22 \mathrm{~mm} \mathrm{y}^{-1}$ is higher than the satellitederived global rate of $3.4 \mathrm{~mm} \mathrm{yr}^{-1}$ (Nerem et al. 2010; see http://sealevel.colorado.edu/).

With regard to the relationship with ENSO, the pronounced 2006-2007 spike in relative sea level coincided with a strong El Niño, as does that which started in 2015. However, the spikes that occurred in 2012 and 2013 associate with a La Niña episode or a weak El Niño. Positive El Niño episodes are superimposed on generally rising trends in temperature and sea level. Thermal expansion is responsible for more than one-third of sea level rise, and these monthly sea level and water temperature data are indeed very strongly positively correlated $(\mathrm{r}=0.400, \mathrm{~N}=128, \mathrm{p}<.001)$.

\section{DISCUSSION}

\section{Temperatures and Coral Cover}

It is not only the relatively recent major global events of 1998 and 2015-2017 that have caused overall coral cover to decline in this archipelago. During the period of 1979 to 1996, no research took place in the archipelago. During this time, overall coral cover decreased appreciably in Chagos, perhaps partly as a result of the severe worldwide warming event that occurred in 1982-1983 which is known to have had severe biological consequences (Barber and Chavez, 1983). Some important shallow water species such as Isopora palifera (previously known as Acropora palifera) were largely eliminated during that time (Sheppard, 1999). I. palifera was the main wave-breaking shallow species facing northwest and, while still present with numerous small colonies, is functionally absent at present in terms of its breakwater effect.

After the 1998 event, recovery did not take place at all for three years (Sheppard et al., 2002), but was relatively rapid after 2001. Coral cover had recovered to levels seen before the 1998 event by about 2010 until the severe and prolonged 2015 event began. Several factors may help explain why there was rapid recovery in the intervening years. It has been suggested that the cool temperature plunges during the warmest time of each year offered respite from anomalously high water temperature for the corals (Sheppard, 2009). Secondly, there are no direct, local human impacts to the reef that inevitably flow from habitation.

\section{Juveniles and Survivors}

The existence of juvenile corals is a predictor of coral recovery in future years. Recovery might be driven by either current-borne larvae from further afield or local reseeding, or both. Although numbers of juveniles were greatly reduced in 2017 they were at least still present. Numerous small corals larger than our defined cutoff of $15 \mathrm{~mm}$, were also seen to exist, suggesting that those corals, approximately 2 to 4 years old, had persisted through the mortality event and that their small size did not appear to prejudice survival. Not only were Psammocora species and Pavona varians the most common corals in terms of $<15 \mathrm{~mm}$ juveniles, they were also common in the larger groups of $15 \mathrm{~mm}$ to $4 \mathrm{~cm}$. Psammocora spp. and Pavona varians were also the species shown to be the most common coral during the 1970s (Sheppard, 1980). Faviids and species of Acropora were nearly as prevalent, and although the latter occurred mostly on dead tables, their presence clearly showed that reproduction, or larval transport from elsewhere, was still taking place.

Relevant to this is the survivorship of fragments of older colonies. In these instances some polyps on much older colonies, such as massive Porites, persisted through the warming, and those polyps were already expanding over the dead surface of the skeleton (Figure 16). This process might be important for future recolonization. Furthermore, in the 'transition zone' between $10 \mathrm{~m}$ and $15 \mathrm{~m}$, numerous colonies 


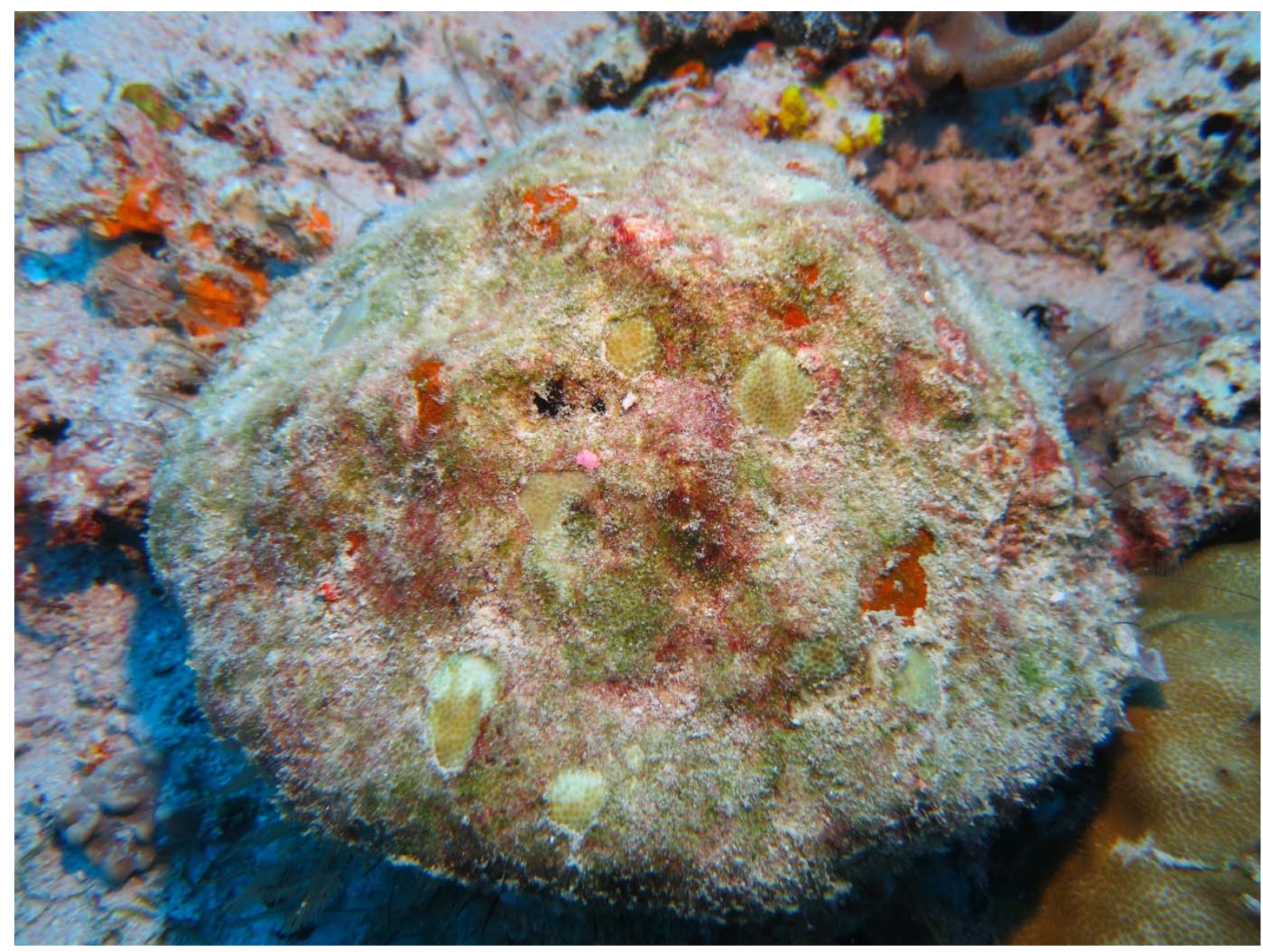

Figure 16. A massive Porites colony which was mostly killed in 2015-2016 where several polyps appear to have survived in patches and which, in 2017, are expanding their live cover over the old, dead surface.

were seen on which only the illuminated, upward facing surfaces were killed, with living tissue surviving on the more shaded sides (Figure 17). Bleaching and mortality has long been known to be caused by intensity of illumination in conjunction with overall temperature regime (Jones et al., 1998).

\section{Species Survivors and Disappearances}

About 300 reef building species are known to occur in the Chagos atolls (http://chagosinformationportal.org/corals). The degree of survivorship between different species is great. Species of Acropora were highly susceptible to bleaching-induced mortality, especially tabular and arborescent forms, as was the closely related and very important shallow species Isopora palifera. Most of the smaller digitate corals Pocillopora and Stylophora were similarly very susceptible. All these are relatively fast-growing and were seen to provide high cover and greater 3-D structure just a few years following earlier bleaching events. Within Porites, there was almost complete elimination of branching forms and of Porites rus, whose dead colonies, along with other leafy forms, had covered most of the shallow Salomon Atoll lagoon but were almost totally killed in 2012. Some small massive members of Porites were survivors, and indeed were the only ones, in shallow water between approximately $2 \mathrm{~m}$ to 4 $\mathrm{m}$ deep. 


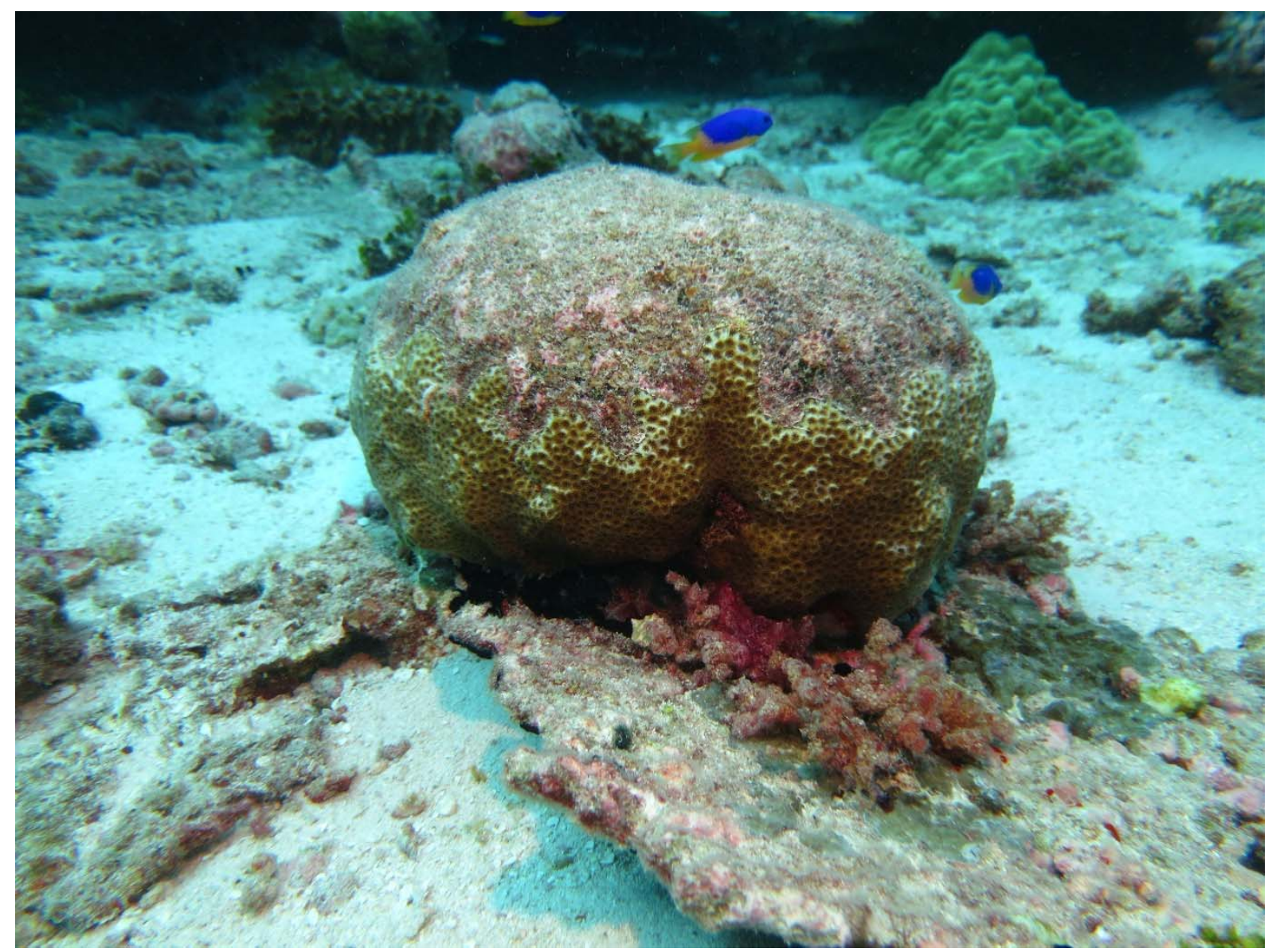

Figure 17. Example of a coral colony (Leptastrea sp.) at the 'transition zone around $15 \mathrm{~m}$ depth, where mortality ceased to be near total, where the upper, illuminated surface has been killed in 2015-2016 but where the shaded portion of the colony survived.

The large, formerly common massive coral Diploastrea heliopora has not been seen in any of several hundred dives across all atolls since the 1998 warming. All species of the finely branching Seriatopora vanished for about 10 years after 1998; it had been recovering slowly, but was severely reduced again in 2017. In 2017, no living colonies of the formerly common 'Chagos brain coral' Ctenella chagius were seen, and because its distribution is largely restricted to this archipelago, this is of particular concern. Most of the coral species that were severely affected have shallow water distributions so that, for many, there may be few sources of future recruits from colonies in deeper water. Dead coral skeletons of all species in shallow waters were conspicuous for their complete covering by encrusting red algae.

\section{Calcification}

In this archipelago, carbonate production was measured by Perry et al. (2015) in March-April 2015, at the start of the warming. They showed that across 28 reefs studied, net carbonate production rates averaged $+3.7 \mathrm{G}\left(\mathrm{G}=\mathrm{kg} \mathrm{CaCO}_{3} \mathrm{~m}^{-2} \mathrm{yr}^{-1}\right)$, with gross production averaging $+6.6 \mathrm{G}$, and bioerosion rates averaging $3.4 \mathrm{G}$ across all reefs. One-third of all reefs measured had a net carbonate budget of more than +5 G. Importantly, production in 2015 on the Acropora dominated reefs was more than double the 
average rate, at $+8.4 \mathrm{G}$. The carbonate production in 2015 was driven mainly by the genera Acropora, Pocillopora and Porites. These positive budgets are reflected in high reef accretion rates, estimated to be $2.3 \mathrm{~mm} \mathrm{y}^{-1}$ on average, and as much as $4.2 \mathrm{~mm} \mathrm{yr}^{-1}$ on Acropora-dominated reefs.

In contrast, average coral cover in 2017, as seen in Figure 4, was about 10\%, caused in large part by mortality of almost all the Acropora, Pocillopora and Stylophora which had been very abundant in the shallowest $15 \mathrm{~m}$. Perry and Morgan (2017) have performed similar carbonate production estimates in the nearby Maldives in 2016, where the average percent coral cover had similarly fallen to just more than $6 \%$. This shifted the carbonate budget of those atolls from being strongly net positive at +5.9 G previously, as Chagos had been, to strongly net negative $(-2.9 \mathrm{G})$. The implication of this was a reduction in reef growth potential from $+4.2 \mathrm{~mm} \mathrm{y}^{-1}$ to $-0.4 \mathrm{~mm} \mathrm{y}^{-1}$, in other words, the reefs had shifted from a net accretional to a net erosional phase.

While coral production rates have not yet been measured in Chagos atolls since the recent warming event, the analogous results from the adjacent Maldives are clear, and indeed Perry and Morgan (2017) note the similarity between the two archipelagos. Cover values shown for Chagos atolls for 2017 are such that carbonate deposition by corals will have become strongly negative here too, and it is likely that these reefs also will have moved to an erosional state.

\section{Frequencies of Warming Events and Predictions for the Future}

Because recovery after 1998, in terms of coral cover at least, took about a dozen years, recovery might occur again. Unfortunately for these hopes, predictions have been made of the frequency of repeat mortality events derived from work merging historic and forecast SST data from the Hadley Centre (Sheppard, 2003). It was suggested then that the date when repeat warming episodes would recur too frequently for corals to reproduce would occur sometime in the mid-2020s for Chagos, similar to the date predicted for many other low latitude reef systems in the Indian Ocean. Using somewhat different methods carried out at finer scale, this prediction has been confirmed by recent studies (van Hooidonk et al., 2016), who also suggest that such an 'end point' for these reefs might occur during the 2020s. Further, Heron et al. (2017) have recently suggested that under present warming trends, almost all reefs systems in UNESCO World Heritage Sites (WHS) will experience bleaching events twice per decade by 2040. The nearest WHS to the Chagos reefs is Aldabra in the Seychelles, of similar latitude further west, and which has projected dates of 2028 to 2032 for reaching the point of twice decadal mass mortality (Heron et al., 2017) which is potentially terminal. If this turns out to be the case, there will be little scope for the reefs of Chagos to return to either a healthy ecological state or to a condition of net carbonate accretion from their present state. Frieler et al. (2013) have shown that limiting global warming to even $2^{\circ} \mathrm{C}$ is unlikely to save most coral reefs. With warming of $2^{\circ} \mathrm{C}$, the most optimistic assumptions predict that one-third of reefs will decline, and under more realistic ones possibly two-thirds will severely decline.

Ultimately, coral growth at the individual level underpins both ecological functioning and accretion of coral reefs. Loss of reefs also reduces their breakwater function, leading to erosion of island shorelines as has been shown in Diego Garcia, the only permanently inhabited Chagos atoll (Purkis et al., 2016) and in the Seychelles (Sheppard et al., 2005).

Coupled with coral mortality and loss of reef growth, sea level rise adds an additional problem. In Diego Garcia the rate of rise is higher than the oceanic average, presumably because of some subsidence at that atoll. Atoll subsidence is of course how atolls are formed (provided reef development keeps pace with relative sea level rise from subsidence and eustacy) and, while the majority of these atolls may show some subsidence, there is no information on rates on other atolls in the group.

Earlier work has shown that while some island dune and berm systems on Diego Garcia may extend a few metres above high tide level, this is not the case in most of the islands. In Diego Garcia, which contains approximately half of the land area of the whole archipelago, most of the land lies within a meter of the high tide level. Profiles show that a very high proportion of all atolls lie very close to, or even below sea level (Stoddart, 1971; Purkis et al., 2016, fig. 13; Sheppard, 2002, figs. 5-7). Healthy corals are 
required to maintain growth rates of reefs that can match rates of sea level rise. Further, the reef crests in the Chagos Archipelago that provide a breakwater effect are often located close to islands, from sometimes only $25 \mathrm{~m}$ from the shorelines. Where this is the case, these relatively short distances mean that the breakwater effect of reefs is reduced because of the limited distances over which waves can become attenuated (Sheppard et al., 2005; Storlazzi et al., 2016). The consequences of continued or prolonged erosion of reefs could therefore become severe.

The prognosis is concerning, not only from a scientific perspective. The reason for the existence of the political unit of the British Indian Ocean Territory, in which these atolls are the only land, is the military facility in the southernmost Diego Garcia Atoll. It is the existence of this facility that has helped ensure that there are no local impacts of sewage and other forms of pollution that are inimical to coral growth. As noted in a security report that considered consequences of sea level rise (Foley, 2012, 3), Diego Garcia is one of the top five "most vulnerable" military installations in the world. Also: "The island is extremely vulnerable to the effects of climate change ... If the island is flooded or inundated completely, the US will lose a strategically vital installation in the most tumultuous region in the world." Erickson et al. (2013) reaffirm the importance of Diego Garcia in military terms, and the warnings about climate change in general are enumerated by a panel of Generals and Admirals (CNA Military Advisory Board, 2014) who emphasise both the threats to western security and the high cost of countering such climate-induced changes. They also note that these impacts and costs are accelerating faster than they had concluded in their earlier 2007 report. The latter emphasised that: "Actions by the United States and the international community have been insufficient to adapt to the challenges associated with projected climate change. Strengthening resilience to climate impacts already locked into the system is critical, but this will reduce long-term risk only if improvements in resilience are accompanied by actionable agreements on ways to stabilize climate change" (CNA Military Advisory Board, 2014, 1). That panel in fact felt compelled to update their earlier report because of their "growing concern over the lack of comprehensive action by both the United States and the international community to address the full spectrum of projected climate change issues."

These conclusions were reached when corals had largely recovered from earlier mass moralities and before the effects of 2015-2017. It is clear that for these reefs to continue to accrete and survive in a productive way, the single most important issue to be addressed is that of periodic warming episodes that result in massive mortality of the reef building corals. Warming and sea-level rise will result in greater inundation of such islands (Storlazzi et al., 2015). The frequency of recurrence of warming water which impedes coral recovery will be critical to long term function of the Chagos reefs.

\section{ACKNOWLEDGEMENTS}

We are grateful to the BIOT Administration Section of the FCO for granting permits to work in BIOT, and to the crews of the BIOT Patrol Vessels Pacific Marlin and Grampian Frontier. The earlier expeditions were funded through grants from OTEP and DfID and later from the DEFRA Darwin Initiative, while since 2016 the Bertarelli Foundation has been the main source of funding for this work. In 2015, logistical field support was provided by the crew of the M/Y Golden Shadow, through the generosity of HRH Prince Khaled bin Sultan. A grant to the NERC National Facility for Scientific Diving from the NERC Services and Facilities capital equipment scheme funded the software and hardware used

to generate the photogrammetric models. D.B. was funded by a NERC DTP studentship. Two anonymous reviewers provided comments that improved the manuscript.

\section{REFERENCES}

Ateweberhan, M., T. R. McClanahan, N. A. J. Graham, and C. R. C. Sheppard. 2011. Episodic 
Heterogeneous Decline and Recovery of Coral Cover in the Indian Ocean. Coral Reefs, 30:739-752.

Ateweberhan, M., D. A. Feary, S. Keshavmurthy, A. Chen, M. H. Schleyer, C. R. C. Sheppard. 2013. Climate Change Impacts on Coral Reefs: Synergies with Local Effects, Possibilities for Acclimation, and Management Implications. Marine Pollution Bulletin, 74:526-539.

Barber, R. T. and F. P. Chavez. 1983. Biological Consequences of El Niño. Science, 222:1203-1210.

Burns, J., D. Delparte, R. Gates, and M. Takabayashi. 2015. Integrating Structure-From-Motion Photogrammetry with Geospatial Software as a Novel Technique for Quantifying 3D Ecological Characteristics of Coral Reefs. PeerJ, 3:e1077.

CNA Military Advisory Board. 2014. National Security and the Accelerating Risks of Climate Change Alexandria, VA: CNA Corporation. 45 pp.

Edgar, G. J. and 24 others. 2014. Global Conservation Outcomes Depend on Marine Protected Areas with Five Key Features. Nature, 506:216-220. https://doi.org/10.1038/nature13022.

Erickson, A., W. Ladwig, and J. Mikolay. 2013. Diego Garcia: Anchoring America's Future Presence in the Indo Pacific. Asia Harvard Quarterly, 15.2:20-28.

Foley, C. 2012. Military Basing and Climate Change. Climate Security: American Security Project. https://americansecurityproject.org/wp-content/uploads/2012/11/Military-Basing-and-ClimateChange.pdf.

Frieler, K., M. Meinsausen, A. Golly, M. Mengel, K. Lebek, S. D. Donner, and O. Hoegh-Gulldberg. 2013. Limiting Global Warming to 2 Degrees C Is Unlikely to Save Most Coral Reefs. Nature Climate Change, 3:165-170.

Heron, S. F., J. A. Maynard, R. van Hooidonk, and C. M. Eakin. 2016. Warming Trends and Bleaching Stress of the World's Coral Reefs 1985-2012. Scientific Reports 6, Article No. 38402.

Heron, S. F., C. M. Eakin and F. Douvere. 2017. Impacts of Climate Change on World Heritage Coral Reefs: A First Global Scientific Assessment. Paris, UNESCO World Heritage Centre, 16 pp.

Hughes, T. P., and 46 others. 2017. Global Warming and Recurrent Mass Bleaching of Corals. Nature 543:373-377. https://doi.org/10.1038/nature21707.

IOC 2017. http://www.ioc-sealevelmonitoring.org/station.php? code=garc

IPCC. 2014. Climate Change 2014: Synthesis Report. Contribution of Working Groups I, II and III to the Fifth Assessment Report of the Intergovernmental Panel on Climate Change [Core Writing Team, R. K. Pachauri and L. A. Meyer (eds.)]. IPCC, Geneva, Switzerland. 151 pp.

Jones, R. J., O. Hoegh-Guldberg, A. W. D. Larkum, and U. Schreiber. 1998. Temperature-Induced Bleaching of Corals Begins with Impairment of the CO2 Fixation Mechanism in Zooxanthellae. Plant, Cell and Environment, 21:1219-1230.

Kohler, K. E., and S. M. Gill. 2006. Coral Point Count with Excel Extensions (CPCe): A Visual Basic Program for the Determination of Coral and Substrate Coverage Using Random Point Count Methodology. Computers and Geosciences, Vol. 32(9):1259-1269.

Liu, G., A. E. Strong, and W. Skirving. 2003. Remote Sensing of Sea Surface Temperature during 2002 Barrier Reef Coral Bleaching. EOS, 84:137-144.

Nerem, R. S., D. Chambers, C. Choe, and G. T. Mitchum."Estimating Mean Sea Level Change from the TOPEX and Jason Altimeter Missions." Marine Geodesy 33(1), supp. 1 (2010):435. https://doi.org/10.1080/01490419.2010.491031.

NOAA. 2015. NOAA Declares Third Ever Global Coral Bleaching Event. http://www.noaanews.noaa.gov/stories2015/100815-noaa-declares-third-ever-global-coral-bleachingevent.html.

NOAA. 2016a. Global Climate Report - Annual 2016. https://www.ncdc.noaa.gov/sotc/global/201613

NOAA. 2016b. Extended Reconstructed Sea Surface Temperature (ERSST.v4). National Centers for Environmental Information. www.ncdc.noaa.gov/data-access/marineocean-data/extendedreconstructed-sea-surface-temperature-ersst (accessed March 2016).

Perry, C. T., G. N. Murphy, N. A. J. Graham, S. K. Wilson, F. A. Januchowski-Hartley, and H. K. East. 2015. Remote Coral Reefs Can Sustain High Growth Potential and May Match Future Sea-Level Trends. Scientific Reports 5, Article No. 18289. https://doi.org/10.1038/srep18289. 
Perry, C. T., and K. M. Morgan. 2017. Bleaching Drives Collapse In Reef Carbonate Budgets and Reef Growth Potential on Southern Maldives Reefs. Scientific Reports 7, Article No. 4058. https://doi.org/10.1038/srep40581.

Purkis, S. J., R. Gardiner, M. W. Johnston, and C. R. C. Sheppard. 2016. A Half-Century of Coastline Change in Diego Garcia - The Largest Atoll Island in the Chagos. Geomorphology, 261: 282-298.

Roberts, C. M., and 11 others. 2017. Marine Reserves Can Mitigate and Promote Adaptation to Climate Change. PNAS, 114:6167-6175. https://doi.org/10.1073/pnas.1701262114.

Schlager, W., and S. J. Purkis. 2013. Bucket Structure in Carbonate Accumulations of the Maldive, Chagos and Laccadive Archipelagos. International Journal of Earth Sciences, 102:2225-2238.

Sheppard, C. R. C. 1980. Coral Cover, Zonation and Diversity on Reef Slopes of Chagos Atolls, and Population Structures of the Major Species. Marine Ecology Progress Series, 2:193-205.

Sheppard, C. R. C. 1999. "Changes in Coral Cover on Reefs of Chagos Atolls over Eighteen Years." In Ecology of the Chagos Archipelago. Occasional Publications of the Linnean Society of London, Vol. 2, ed. C. R. C. Sheppard and M. R .D. Seaward, pp. 91-100. London: Westbury for the Linnean Society of London.

Sheppard, C. R. C. 2002. Island Elevations, Reef Condition and Sea Level Rise in Atolls of Chagos, British Indian Ocean Territory. Cordio, Vol 3, pp. 202-211.

Sheppard, C. R. C. 2003. Predicted Recurrences of Mass Coral Mortality in the Indian Ocean. Nature, 425:294-297.

Sheppard, C. R. C. 2009. Large Temperature Plunges Recorded by Data Loggers at Different Depths on an Indian Ocean Atoll: Comparison with Satellite Data and Relevance to Coral Refuges. Coral Reefs, 28:399-403.

Sheppard, C. R. C., M. D. Spalding, C. Bradshaw, and S. Wilson. 2002. Erosion vs Recovery of Coral Reefs after 1998 El Nino: Chagos Reefs, Indian Ocean. Ambio, 31:40-48.

Sheppard, C. R. C., and 40 others. 2012. Reefs and Islands of the Chagos Archipelago, Indian Ocean: Why It Is the World's Largest No-Take Marine Protected Area. Aquatic Conservation: Marine and Freshwater Ecosystems, 22:232-261.

Sheppard, C. R. C., and 16 others. 2013. "Coral Reefs of the Chagos Archipelago, Indian Ocean." In Coral Reefs of the British Indian Ocean Territories, ed. C.R.C Sheppard, chapter 18, pp. 241-252. Dordrecht, Netherlands: Springer.

Sheppard, C. R. C., D. J. Dixon, M. Gourlay, A. L. S. Sheppard, and R. Payet. 2005. Coral Mortality Increases Wave Energy Reaching Shores Protected by Reef Flats: Examples from the Seychelles. Estuarine, Coastal, and Shelf Science, 64:223-234. https://doi.org/10.1016/j.ecss.2005.02.016.

Stoddart, D. R. 1971. Geomorphology of Diego Garcia Atoll. Atoll Research Bulletin, 194:7-26.

Storlazzi, C. D., E. P. L. Elias, and P. Berkowitz. 2015. Many Atolls May Be Uninhabitable within Decades Due to Climate Change. Scientific Reports 5, Article No. 14546.

Strong, A. E., G. Liu, J. Meyer, J. C. Hendee, and D. Sasko. 2004. Coral Reef Watch 2002. Bulletin of Marine Science, 75:259-268.

van Hooidonk R., and 8 others. 2016. Local-Scale Projections of Coral Reef Futures and Implications of the Paris Agreement. Scientific Reports 6, Article No. 39666. https://doi.org/10.1038/srep39666.

Veron, J. E. N., M. Stafford-Smith, L. DeVantier, and E. Turak. 2015. Overview of Distribution Patterns of Zooxanthellate Scleractinia. Frontiers in Marine Science. https://doi.org/10.3389/fmars.2014.00081.

Wolter, K., and M. S. Timlin. 1998. Measuring the Strength of ENSO—How Does 1997/98 Rank? Weather, 53:315-324.

Westoby, M. J., J. Brasington, N. F. Glasser, M. J. Hambrey, and J. M. Reynolds. 2012. "Structure-fromMotion” Photogrammetry: A Low-Cost, Effective Tool for Geoscience Applications. Geomorphology, 179:300-314.

Wright, J. 2016. Analysing the Relationship between Senescing Acropora Tables and Disease Prevalence in the Absence of Anthropogenic Pressures. Master of Marine Biology Thesis. School of Ocean Sciences, Bangor University, UK. 31 pp. 